\title{
Participatory Action Research for Conservation and Development: Experiences from the Amazon
}

\author{
Stephen G. Perz ${ }^{1, *}$, Marliz Arteaga ${ }^{2} \mathbb{D}$, Andrea Baudoin Farah ${ }^{3}$, I. Foster Brown ${ }^{4,5}$ (D), \\ Elsa Renee Huaman Mendoza ${ }^{6}$, Yara Araújo Pereira de Paula ${ }^{7,8}$, Leonor Mercedes Perales Yabar ${ }^{9}$, \\ Alan dos Santos Pimentel ${ }^{8} \mathbb{D}$, Sabina C. Ribeiro ${ }^{10} \mathbb{D}$, Guillermo Rioja-Ballivián ${ }^{11}$, Martha Cecilia Rosero Peña ${ }^{12}$, \\ L. Cecilia Sanjinez L. ${ }^{13}$ and N. Galia Selaya G. ${ }^{14}$
}

1 Department of Sociology and Criminology \& Law, University of Florida, Gainesville, FL 32611, USA

2 School of Natural Resources and Environment, University of Florida, Gainesville, FL 32611, USA; marliz@ufl.edu

3 Natural Capital Project, Stanford Woods Institute for the Environment and Department of Biology, Stanford University, Palo Alto, CA 94305, USA; abaudoin@stanford.edu

4 Woodwell Climate Research Center, Falmouth, MA 02540, USA; fbrown@woodwellclimate.org

5 Parque Zoobotânico and Centro de Ciências Biológicas e da Natureza, Universidade Federal do Acre, Rio Branco 69920-900, AC, Brazil

6 Earth Innovation Institute, Rua Dourado 142, Rio Branco 69915-002, AC, Brazil; emendoza@earthinnovation.org

7 Fundação de Apoio ao Ensino, Pesquisa, Extensão e Desenvolvimento Institucional do Acre, Rio Branco 69920-900, AC, Brazil; depaula.yap@gmail.com

8 Centro Nacional de Monitoramento e Alertas de Desastres Naturais, São José dos Campos, Sao Paulo 12247-016, SP, Brazil; alan.geopimentel@gmail.com

Citation: Perz, S.G.; Arteaga, M.; Baudoin Farah, A.; Brown, I.F.;

Mendoza, E.R.H.; de Paula, Y.A.P.; Perales Yabar, L.M.; Pimentel, A.d.S.; Ribeiro, S.C.; Rioja-Ballivián, G.; et al. Participatory Action Research for Conservation and Development: Experiences from the Amazon. Sustainability 2022, 14, 233. https:/ / doi.org/10.3390/su14010233

Academic Editors: Alejandro Rescia and Ivo Machar

Received: 8 September 2021

Accepted: 22 December 2021

Published: 27 December 2021

Publisher's Note: MDPI stays neutral with regard to jurisdictional claims in published maps and institutional affiliations.

Copyright: (c) 2021 by the authors. Licensee MDPI, Basel, Switzerland. This article is an open access article distributed under the terms and conditions of the Creative Commons Attribution (CC BY) license (https:// creativecommons.org/licenses/by/ $4.0 /)$.
9 Servicio Nacional Meteorología y Hidrología del Peru, Inapari 17300, Madre de Dios, Peru; leomeche@hotmail.com

10 Centro de Ciências Biológicas e da Natureza, Universidade Federal do Acre, Campus Universitário, BR 364, Km 04 Distrito Industrial, Rio Branco 69920-900, AC, Brazil; sabina.ribeiro@ufac.br

11 Independent Researcher, Cobija, Pando, Bolivia; guillermorioja@gmail.com

12 Center for Latin American Studies, University of Florida, Gainesville, FL 32611, USA; enerosero@gmail.com

13 Area de Ciencias Biológicas y Naturales, Universidad Amazónica de Pando, Cobija, Pando, Bolivia; doctorasanjinez@gmail.com

14 Independent Researcher, Rio Branco 69920-900, AC, Brazil; gselaya@outlook.com

* Correspondence: sperz@ufl.edu; Tel.: +01-352-294-7186

Abstract: Research that features participation and action orientation, such as participatory action research (PAR), is especially valuable in contexts where there is rapid change, high social inequality, and great uncertainty about the future, which drives stakeholder demands for information to support their goals. The Amazon offers such a context, for it is a region where diverse stakeholders engage in contestation over environmental governance to address issues such as climate change to achieve conservation and sustainable development. Stakeholder mobilization has changed the terms by which research is conducted, from the definition of priority topics to the application of findings. Due to stakeholder mobilization, more and more research in the Amazon is now necessarily participatory, for stakeholders routinely issue demands about how the research will be conducted and for what purpose. In this paper, we provide an overview of several experiences of implementing methods such as PAR by different teams or networks, focusing on the complementary contributions of outside researchers and local stakeholders. The heart of the paper reports on three broad types of experiences focusing on conservation and development in the Amazon: (1) participatory data collection for co-production of knowledge for environmental governance, (2) inclusive environmental monitoring systems, and (3) innovative models of knowledge exchange to facilitate collective action. Within each type, we report multiple experiences with distinct approaches to participation and action in research. These experiences constitute models that can be replicated in other places for broader impact to support conservation and development.

Keywords: sustainability; conservation; development; governance; participatory action research; climate; infrastructure; indigenous; stakeholder; Amazon 


\section{Introduction}

The UN Sustainable Development Goals (SDGs) highlight a suite of priorities to harmonize human well-being with environmental conservation [1]. Recent reviews of the implementation of the SDGs have highlighted the importance of broad stakeholder participation [2,3]. A key to the implementation of the SDGs is stakeholder participation in knowledge management [4,5]. Broad participation in knowledge management, including participation in research, can permit knowledge mobilization, the translation of knowledge into collective action for sustainability [6-9].

Participatory action research (PAR) provides a collaborative approach to knowledge management and mobilization [10,11]. In PAR, researchers and stakeholders collaborate across the various stages of the research process, beginning with the joint definition of research priorities and continuing to design, data collection, analysis, dissemination, and application of findings. Ideally, it is stakeholders who define the research focus as related to concrete objectives that serve their strategic goals. There is extensive literature on PAR and related approaches in which stakeholders and researchers pursue knowledge management for conservation and sustainability [12-15]. Stakeholders who seek knowledge to support improved environmental governance for sustainable natural resource management have priorities that can drive research for action.

PAR and related methods are especially valuable in developing regions and other contexts where there is rapid change, high inequality in access to information, and great uncertainty about the future. Under such conditions, stakeholders have a high demand for information on topics related to their strategic goals. Equally, such conditions magnify the challenges to approaches such as PAR in developed countries, notably the inclusion of marginalized voices (women, indigenous peoples, young people, etc.) [16-18].

In this paper, we take up the case of the Amazon and focus on how PAR and related approaches can support environmental conservation and sustainable development there. We report a diverse set of recent experiences in the western Amazon involving different teams or networks, with the goal of showing how researchers and local stakeholders have developed innovative models involving elements of PAR to support conservation and development. We begin with a review of a constellation of literature on approaches related to PAR. We then focus on a conceptual framework for PAR as a process, highlighting the distinct contributions of researchers and stakeholders at various stages. The main section of the paper discusses a suite of experiences in the western Amazon. While the cases are independent of each other, they all respond to stakeholder demand for greater participation in research and exhibit an action orientation to address conservation and development. We report on three types of experiences, drawing on six cases in which stakeholders and researchers collaborated in a participatory mode in ways that supported stakeholder goals. Each case presents certain innovations with regard to the details of stakeholder participation and the applications of research findings to conservation and development. We conclude with a comparative discussion of the experiences reported, along with comments on the emerging challenges for PAR practice in developing regions such as the Amazon.

\section{Background}

\subsection{Approaches to Participatory Action Research}

There is a constellation of scholarly literatures on research and practice pertinent to PAR on conservation and development issues. Here we briefly comment on selected publications on (1) trans-disciplinarity, (2) traditional ecological knowledge, (3) decolonization of research, (4) the democratization of knowledge, (5) knowledge exchange, (6) citizen science, and (7) knowledge co-production. We suggest that each offers an in-depth contribution to elements of PAR.

Trans-disciplinarity refers to the conduct of research that goes beyond a researcher's home discipline and academia in general. This differentiates trans-disciplinarity from multidisciplinarity, which refers to collaboration among researchers from different disciplines 
who make contributions according to their respective specialties, and interdisciplinarity, in which researchers from different disciplines work toward a synthesis by integrating their contributions [19]. Trans-disciplinarity is, by definition, a participatory mode of conducting research that features the contributions of non-academic stakeholders. Key in trans-disciplinarity are specific communicative practices to support the inclusion of diverse stakeholders [20-23]. One key element in trans-disciplinarity concerns the explicit acknowledgment and incorporation of stakeholder priorities in defining the topics for research. Another concern is with the media to permit dialogue between researchers and stakeholders, in which storytelling (to narrate processes and causation) and visual representations (including images with culturally recognized symbols, infographics, and videos) are often vital tools.

Against western systems of thought, there has been recognition of traditional ecological knowledge (TEK) among indigenous groups and other traditional peoples about local ecosystems [24,25]. TEK is often rooted in long-term practices based on deep histories of firsthand experience. Acknowledgment of TEK goes beyond simply noting that local peoples may have knowledge that western scientists do not, for TEK is frequently grounded in non-western ontologies and belief systems. Recognizing TEK thus requires acknowledgment of the spiritual aspects of traditional knowledge systems [26]. Insofar as threats to ecosystems are associated with threats to local cultures, conservation and development work featuring TEK often relies on the application of participatory methods to rescue or recover TEK [27]. In turn, there are opportunities to combine TEK with western science and collaborative enterprises to support sustainable resource management $[28,29]$.

TEK can be seen as consonant with calls for the decolonization of research. This refers to a shift from research as a neocolonial enterprise initiated and managed by western researchers for the purpose of extracting information to research as a liberating endeavor led by local peoples using ontologies and methods they developed for purposes they defined. Decolonization of research thus valorizes local approaches to knowledge management, such as those grounded in indigenous ontologies, and featuring methods such as storytelling [30-33]. This requires a period of cultural immersion on the part of outside researchers and activities to build trust with local peoples. In the process, it is the outsiders who learn, but the knowledge acquisition features non-western ontologies and local practices by which knowledge can be acquired and shared. Decolonization of research can thus acknowledge TEK as well as the practices for knowledge management that support it, and, in turn, permit knowledge mobilization and other action.

The democratization of knowledge argues for a broadly inclusive approach to stakeholder participation in the production as well as access to knowledge for conservation and development $[34,35]$. Scholars who advocate for the democratization of knowledge often feature the perspectives and priorities of subaltern stakeholder groups such as the poor and disadvantaged $[36,37]$. Work on the democratization of knowledge is also broadly conceived with regard to the various aspects of knowledge management (production, access, application) and stages of research (problem definition, data collection, analysis, etc.).

Knowledge exchange offers a means of democratizing knowledge. Knowledge exchange refers to the exchange of knowledge among groups of stakeholders. This has been applied in numerous contexts [38,39]. It is established in previous work on conservation and development as a key form of engagement between researchers and stakeholders [40,41], including in the Amazon [42,43]. Knowledge exchange is especially valuable among diverse stakeholders with different knowledge funds. Under those conditions, knowledge exchange plays the crucial role of permitting the sharing of complementary information, thus that all participants benefit by learning. The dynamic of sharing complementary knowledge often reveals opportunities for collaborative inquiry and action [19].

Citizen science can animate calls for democratization of knowledge by valorizing the participation of non-academic stakeholders in scientific data collection [44-46]. For environmental applications, citizen science may involve activities such as environmental monitoring, illegal resource use, the status of ecosystem services, or environmental pol- 
lution $[47,48]$. Citizen science may involve collaboration with researchers in one or more stages of the inquiry. It is often, however, motivated by stakeholder priorities on challenging the conclusions of authorities, often governments, about issues of health and safety, notably environmental health. Citizen science thus often pairs stakeholder data collection with reporting, whether to other stakeholders, outside researchers, and/or authorities. Consequently, citizen science can strengthen communities of practice as regards knowledge management, including for concerns with resource management and environmental pollution [49].

The foregoing approaches can be seen as constituting various forms of knowledge co-production. Generally speaking, knowledge co-production involves research activities in which researchers and stakeholders collaborate in a non-hierarchical mode to integrate their knowledge to achieve new insights [50-53]. Knowledge co-production requires the active involvement of both researchers and stakeholders at all stages of the research process. This is necessary because knowledge funds, experiences, and interpretations from both groups are seen as contributing in distinct and complementary ways to the conclusions and thus the applications of the knowledge produced. Knowledge is thus enriched by the diversity of the contributions, which, in turn, facilitates applications, especially via joint action.

These and other traditions of inclusive approaches to research can be seen as constituting specific elements of PAR. Many approaches such as trans-disciplinarity, the democratization of knowledge, knowledge exchange, citizen science, and knowledge co-production offer broad perspectives in terms of stakeholders and less detail about the particular methods, though they all valorize stakeholder input. Others such as TEK and decolonization feature particular types of stakeholders with non-western ontologies such as indigenous groups and thus valorize pursuit of specific methodologies for knowledge management.

\subsection{A Framework for Stakeholder Contributions to PAR}

The foregoing review showed that there are numerous distinct literatures that are relevant to PAR, including in the domain of conservation and development. Previous work on PAR has offered distinct approaches to understanding its constituent processes and key aspects. Many publications on PAR organize their analytical discussions in terms of stages in the research process [54-59]. Many also feature key aspects of PAR, such as the importance of joint reflection [14] or specific approaches such as feminism [60,61] and anti-colonialism [30,62].

We offer a framework about PAR and related methods as a process organized around key stages, shown in Figure 1. The framework calls attention to six key stages (Figure 1, middle row): (1) the definition of a research problem, (2) proposal development in terms of methodology, (3) data collection and compilation, (4) data analysis and interpretation as elements of knowledge co-production, (5) dissemination of results and knowledge exchange, and (6) application of knowledge via collective action. While we present the process as linear, that need not be the case, especially in more inductive research; the figure is a simplification for presentational tractability. We complement prior frameworks by highlighting the distinct contributions of stakeholders (Figure 1, top row) and researchers (Figure 1, bottom row) in each of these stages. At each stage, we note key activities as suggestive examples rather than a definitive rendering of all possible research processes, which are likely to vary among specific contexts. Consequently, the contributions in Figure 1 are not intended to be narrowly prescriptive. 
Contributions of stakeholders:

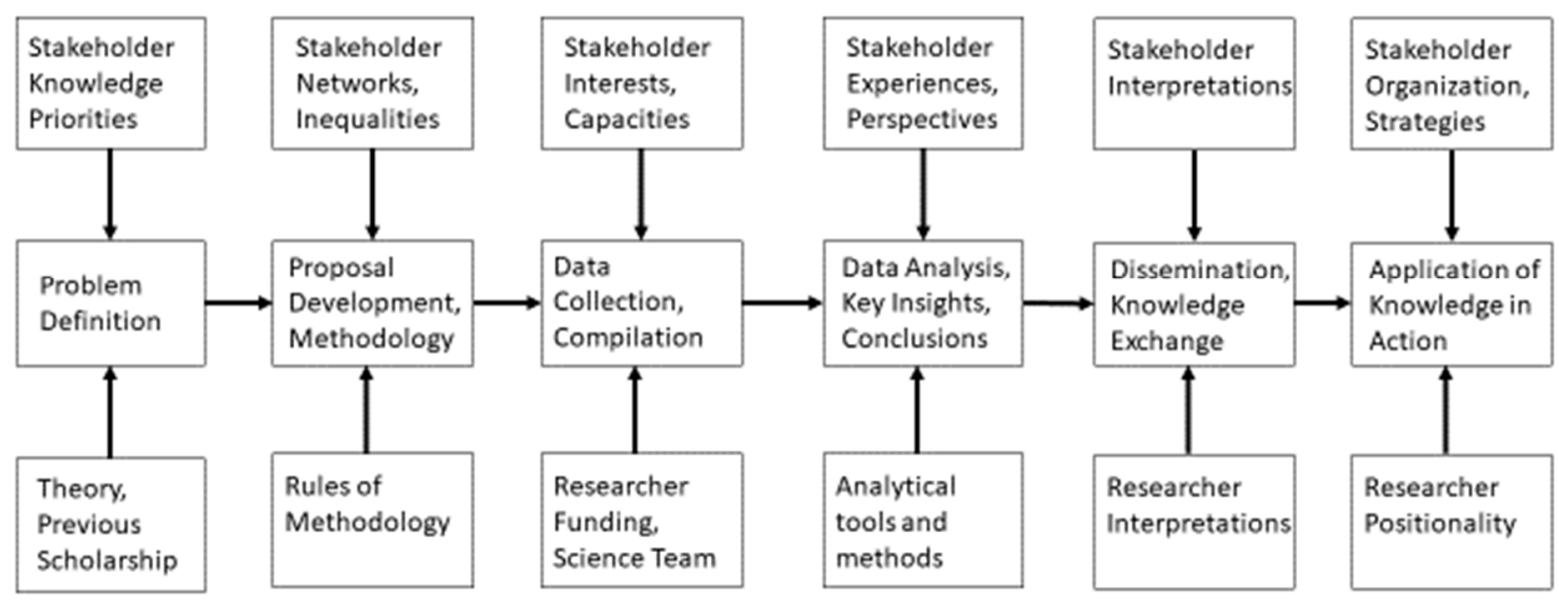

Contributions of researchers:

Figure 1. Conceptual framework for stakeholder and researcher contributions in different stages of the research process.

With regard to problem definition, work on PAR and related methods have recognized the importance of including stakeholders from the beginning of the research process. Whereas researchers may bring knowledge involving theoretical perspectives about relationships among key concepts and findings from previous work on the topic at hand, stakeholders also offer crucial contributions. In particular, as the TEK and other literature have shown, stakeholders bring deep knowledge about the histories and intricacies of local cases. Such knowledge may be crucial for informing theoretical expectations by researchers, particularly in cases where conditioning factors may differ from those of cases studied previously. Even more importantly, stakeholders bring specific priorities about the knowledge they need based on their own knowledge gaps, notably where those gaps may correspond with limitations in researcher knowledge. It is in such instances that stakeholders make especially important contributions by defining the research problem to suffice not only scientific knowledge gaps, but also local and possibly larger-scale conservation and development priorities.

With the research problem defined, the second stage involves proposal development in terms of methodology. Researchers typically bring a suite of experiences about methods based on known advantages and limitations among alternatives. This can offer a menu of options for stakeholders based on the specifics of their goals about knowledge production. For their part, stakeholders bring important assets such as their extant networks of ties among individuals, communities, and organizations, which influence methodological possibilities about site selection, sampling, and data collection. This stage can reveal inequalities and possible tensions among participating stakeholders, which can pose challenges. That said, the valorization of stakeholder contributions to methodological decisions is likely to broaden participation and deepen the richness of the data collected.

In the third stage, focusing on data collection, participatory approaches to research highlight knowledge co-production. Researchers offer their services in terms of bringing in external funding to permit travel and related logistics, as well as the expertise of a science team, which may be diverse in terms of the disciplines represented. Consequently, researchers make equipment available, conduct observations, ask questions, and compile responses. At the same time, stakeholders actively contribute to that process leveraging their knowledge about the research site's history, their network ties, and their social capital. While the term "data collection" might be taken to imply a one-way transmission of information toward researchers, in PAR and related methods, the process is much 
more dialogic, not only between researchers and stakeholders who provide responses but also among outsiders and locals who jointly engage in the research. That is likely to make the specific methods of knowledge acquisition more flexible as researchers and stakeholders learn together and reflect together on that learning. It is also likely to direct discussion of incoming information to highlight that which responds to the priorities of participating stakeholders.

In the fourth stage, knowledge co-production continues via data analysis and interpretation. Outside researchers may conduct their typical analyses. However, even for canonical methods with standard decision criteria for conclusions such as inferential statistics or biologically important findings, in PAR and similar approaches, stakeholders actively inform discussion of the interpretations and their implications. What is more, in PAR, stakeholders play the key role of evaluating data quality as they square up new findings with their previous experience. Stakeholders also stand to complement researcher interpretations and inferences in terms of implications for ecosystems and communities in the study site.

With co-produced interpretations in hand, in the fifth stage of PAR, researchers and participating stakeholders disseminate findings to other stakeholders and thus engage in knowledge exchange. This broadens the co-production of knowledge, as other stakeholders can critically evaluate the initial interpretations. When there is truly proactive participation by stakeholders in the sense of contributing their own interpretations, this amounts to an increasingly rigorous evaluation of the meaning and implications of the findings. As the literature reviewed above noted, presenting findings may vary depending on the stakeholder constituencies, as by featuring storytelling or visual media. However, the goal is the same regardless of medium: collective and participatory evaluation of the findings to derive one or many interpretations and, in turn, develop a discussion of their implications for action.

In the sixth and final stage of PAR, researchers and stakeholders contribute to applying the findings in various forms of collective action. While researchers may lead on some kinds of action, such as issuing reports to scientific outlets or policy makers, PAR's valorization of stakeholder contributions implies that stakeholder strategies will guide most action. Whether by contacting the press, sharing content on social media, seeking meetings with decision-makers, forming new alliances, or various kinds of direct action, stakeholders have numerous options. Of course, the role of researchers in stakeholder-led actions depends on researcher positionality with regard to the stakeholders and the topics, as well as the specifics of the actions to be pursued. Stakeholders may underscore the role of researchers as scientists to support the credibility of the conclusions and the consequent actions proposed. Alternatively, researchers may step back if stakeholders decide on a more political avenue of action involving confrontations with authorities.

\section{Methods: Case Studies of PAR for Conservation and Development in the Amazon}

This paper takes up the case of the western Amazon, well-known for its biodiversity and deforestation, and related issues of species loss and climate change [63,64]. It is also well-known for its diverse stakeholders, ranging from indigenous groups and forest extractivists to small-scale farmers, large-scale ranchers, agribusinesses, fishers, miners, loggers, and others, who often engage in conflicts over natural resources [65-67]. The Amazon is an arena where numerous conservation policies have been advanced, ranging from land-use laws (in protected areas, indigenous territories, sustainable use areas, and state forests) to supply chain regulations, payment for ecosystem service programs, and many others [68-70].

Amidst the debates about conservation and development in the Amazon, a substantial amount of research has also been conducted, often by scholars from outside the region. Historically, research in the Amazon was not highly participatory in terms of the inclusion of local stakeholders. Those days are past. Many stakeholders, such as community associations, indigenous federations, producer cooperatives, and labor unions, have mobilized to 
increase their influence in the governance of natural resources, which has led to demands for specific information [71-73]. Such demands have led to increased stakeholder participation in research, often in a PAR mode of defining research foci and accompanying the process to applications of findings [71,74,75]. Consequently, the range of approaches and models for PAR in the Amazon has broadened. This makes the Amazon a useful context in which to examine a diversity of concrete experiences with distinct methods involving elements of PAR and related approaches. The many experiences available permit not only a review of their goals and the details of their implementation but also their outcomes and lessons learned.

The remainder of this paper therefore reviews several experiences as implemented in the western Amazon with regard to conservation and development. Each case involves a distinct approach to PAR with particular methods, featuring (1) the active participation of local and regional stakeholders via concrete contributions during the process, wherein (2) the research conducted led to collective action to advance conservation and development. Our presentation of the findings therefore cites our sources that outline the particular methods behind each case. Hence, each case builds on previously reviewed methods and findings. Because the methods vary among cases, we do not go into those details here. For each experience, we spell out the basics of the case (location, conservation issue, key stakeholders, and focus of the PAR effort), followed by a description of the PAR methods pursued, highlighting how they were participatory and action-oriented, and concluding with key products and outcomes, along with reflections on lessons learned.

\section{Findings: Experiences of PAR in the Western Amazon}

Each co-author contributed to one of six case studies of PAR for conservation and development in the Amazon. To organize our presentation of the findings from these experiences, this section differentiates among three broad types of experiences with PAR: (1) participatory data collection for co-production of knowledge, (2) inclusive environmental monitoring systems, and (3) innovative models of knowledge exchange. Within each type of experience, we report multiple empirical cases, each from a different team or network.

\subsection{Participatory Data Collection for Co-Production of Knowledge}

Here we report three experiences where outside researchers engaged local stakeholders in participatory processes of data collection to serve stakeholder goals tied to environmental governance. Specifically, this section reports experiences with traditional peoples in Colombia (Rosero), indigenous groups in the TIPNIS area of Bolivia (Baudoin), and a diversity of stakeholders along rivers in the Upper Madeira watershed at the frontier between Bolivia and Brazil (Arteaga and Sanjinez).

\subsubsection{Participatory Research on Resilience to Support Planning for Climatic Crises in Colombia}

In the Amazon and elsewhere, indigenous and other traditional peoples who rely on natural resources for their livelihoods face external threats such as climate change [76,77]. That has prompted questions of adaptation among indigenous and traditional peoples, who often have deep histories of experience in managing natural resources through periods of change [78]. In particular, the prospect of disasters due to climate change and other external shocks to indigenous cultures has led to discussions of resilience among traditional peoples [79].

The focus on resilience carries advantages with regard to understanding external shocks and indigenous adaptation [80]. Resilience offers a positive agenda of supporting adaptability and has driven many public policies for mitigating the impacts of climate change on local livelihoods $[81,82]$. A resilience approach can permit evaluations of the adaptive capacity of diverse cultural groups.

However, resilience is typically conceptualized in the context of western science, which is situated in a dualistic ontology [80]. This differs profoundly from the relational ontologies 
of indigenous cultures [83]. Whereas dualistic ontologies highlight distinctions among categories of a domain, relational ontologies highlight relationships among components of a system. Politically, western dualism justified unequal power relations between European colonizers and subaltern indigenous peoples [83,84]. Consequently, evaluation of the resilience of indigenous and other traditional societies with relational ontologies is likely to be inadequate for understanding the relationships of indigenous and other traditional peoples to their territories, ecosystems, and the natural resources on which they depend. An approach that incorporates relational ontological elements is required for a sufficient evaluation [85].

The incorporation of relational ontologies necessitates a participatory approach to research. It is only by engaging indigenous and traditional peoples and via their relational ontologies that their resource management practices can be understood and their resilience evaluated. This is because relational ontologies involve locally specific systems of values, beliefs, and practices.

Rosero [80] reports an experience from the Amazonian piedmont in Colombia involving an Andean indigenous group, the Nasa, and an Afro-Colombian people, the Dagua, in the state of Cauca and Valle del Cauca, respectively. Both groups exhibit values, beliefs, and practices that reflect relational ontologies with regard to their understandings and management of natural resources in the ecosystems of their traditional territories. At the invitation of community leaders, Rosero [80] therefore met with organizations representing Nasa and Dagua communities in order for them to pursue a participatory process that featured community member contributions about practices of natural resource management as grounded in relational ontologies. The community's objective for the participatory process was to support an evaluation of community resilience in terms of relational ontologies, which in turn served as an input into community planning for future climatic disasters and other shocks.

While Rosero [80] began with an established resilience framework and indicators of social, economic, and cultural resilience, she also implemented participatory workshops with the Nasa and Dagua in which they identified relational ontological elements for incorporation into the evaluation. Relational ontologies became evident in values, beliefs, and practices pertaining to four key themes: (1) attachment to ancestral territory, (2) cultural health care practices, (3) traditional reciprocity practices, and (4) traditional livelihood practices. Here it is important to note that the specific values, beliefs, and practices reported also differed between the Nasa and Dagua. While space limitations prevent a full accounting of the relational ontological elements, we note one for each group as illustrations. The Dagua practice a "navel" ritual (Ombligado) upon the birth of a child, in which the placenta is buried in the ancestral territory and a tree is planted on the spot. The navel ritual encompasses not only a spiritual relationship, tying generations together and attaching people to place while linking birth and death (via burial) in a cycle, but also serves ecological purposes by planting native species important to local livelihoods, thus ensuring social reproduction along with maintenance of native vegetation. Among the Nasa, there are "harmonization" rituals focused on family agricultural plots (Tuls). Harmonization rituals are performed to ensure a balance between people and the universe, manifest in the land and other components of life. Harmonization rituals are thus eminently relational and serve the purpose of refreshing not only social relationships and spiritual balance but also agricultural productivity to support livelihoods.

The key question then concerns the extent to which the Nasa and Dagua follow the traditional practices of their relational ontologies as indicators of their resilience. The participatory workshops were thus followed by surveys of households to determine the extent of those practices. Rosero [80] reported the results of the surveys back to the communities in another round of participatory workshops. In brief, many traditional practices were not universally being implemented; the navel ritual was practiced by roughly $60 \%$ of households among the Dagua, and harmonization rituals were practiced by less than $50 \%$ of households among the Nasa. Those findings provided a basis for community 
planning for future crises, with discussions about the importance of traditional practices as means of preparing for climate change and other external threats. The PAR approach, in which indigenous and other traditional peoples defined the evaluation criteria and then used the findings with those indicators for planning, thus spanned multiple stages of the research process.

4.1.2. Participatory Data Compilation for Autonomous Indigenous Governance of the TIPNIS Area

The Isiboro Sécure Indigenous Territory and National Park (TIPNIS) is located in the department of Beni, in central Bolivia. The TIPNIS is an area of exceptional biological diversity, as it encompasses almost $3000 \mathrm{~m}$ of altitudinal gradient between the foothills of the Andes and the floodable savannas of Moxos in the southern border of the Amazon basin [86]. It is also a culturally diverse area, collectively owned by the Moxeño-Trinitario, Yuracaré, and Chimane peoples since 1990 [86]. During the 1980s and 1990s, these indigenous groups actively worked with NGOs and governmental agencies to advance participatory environmental governance in the TIPNIS [87]. There were collaborative assessments of natural resources, participatory processes to develop, implement and adapt management plans, and active measures to patrol and protect key habitats and species. These experiences strengthened indigenous organizations around trusted leaders and communities of diverse ethnicities.

In the late 2000s and 2010s, conflicts emerged between the peoples of the TIPNIS and the Government of Bolivia. The government proposed the Villa Tunari-San Ignacio de Moxos Highway, which would bisect the TIPNIS area. Indigenous organizations and communities there contested the road project because it would affect core areas of the TIPNIS, important for the integrity of rivers, fisheries, and game, and it would facilitate occupation by colonists [88]. Contestation has taken many forms, from cross-country marches to demands before international courts. A high-profile march in 2011 toward La Paz was met with violence by police forces against the indigenous marchers, which generated international headlines. In 2017 and 2018, TIPNIS indigenous organizations issued complaints against the Bolivian government before the International Rights of Nature Tribunal (IRNT). The IRNT required information to document the rights of indigenous communities, environmental damage due to road construction, and process violations (e.g., lack of consultation and violent repression of protest).

The need to compile information was complicated by the emergence of conflicts among communities in the TIPNIS area. Whereas there had previously been positive experiences of collaboration for environmental governance in the TIPNIS, by the 2010s, indigenous organizations and communities were fractured over the question of the road and their relationships with the Government of Bolivia and each other. For years, indigenous organizations as well as NGO allies had pointed to the need to compile historical documents about institutionalized procedures for governance and management, to no avail due to conflicts and mistrust. Needed was a neutral interlocutor to support the participatory compilation of regional histories and institutions.

In 2018, TIPNIS organizations approached researchers associated with the University of Florida (UF) to establish a partnership. The indigenous organizations had three key priorities: (1) to pursue data compilation to create a regional archive of historical and institutional documents on indigenous governance and management, (2) to organize visits to communities to inform them about the legal proceeding before the IRNT and to collect community member opinions about the highway and the INRT proceeding, and (3) to install or repair two-way radios to improve communication among communities in the TIPNIS. Hence, TIPNIS indigenous organizations defined the priorities for data collection with the intention that they would receive external support and coordinate implementation in order to serve their goals of improving regional environmental governance. With external funding, UF supported all three activities with selected TIPNIS organizations, which coordinated implementation. Indigenous organizations and communities as well as 
local allied stakeholders were engaged in project implementation and the key steps in the research process.

The compilation activity involved a team of UF and TIPNIS collaborators who aimed to create an archive of historical and institutional documents to support the legal claims of TIPNIS indigenous organizations before the IRNT. That supported the larger goals of TIPNIS organizations to reassert their autonomy and rights to manage their territories by recovering their history of environmental governance. The compilation activity required the active participation of current and former TIPNIS indigenous leaders, who were in the best position to identify important documents in local archives. This was especially the case of former indigenous leaders who had led the mobilizations of the late 1980s and early 1990s. The former leaders also helped the team understand the historical significance of certain documents with regard to contemporary struggles and demands. As the team compiled documents, the technical work of locating, scanning, classifying, and organizing them was conducted by local consultants. Once the TIPNIS archive was compiled, it was returned to local indigenous organizations in both print and in digital formats (with hardware for accessing the digital versions).

To support the use of the archive, the team conducted training workshops with detailed user manuals. The workshops included leaders of TIPNIS indigenous organizations and community members. With a subsequent grant, copies of the printed and digital archive were taken to Kateri Tekakwitha Institute, the most important secondary education institution in the TIPNIS. On that occasion, the team conducted workshops with students to discuss the history of the TIPNIS, the importance of collective and institutional memory, and student visions for the future. This activity was partly prompted by research results that pointed towards the lack of intergenerational spaces for institutional knowledge transmission, which hinders long-term governance [87], and thus the need to engage youth in discussions about environmental governance from a historical perspective.

For the community visits activity, indigenous leaders organized the itineraries and led the workshops. The outside collaborators contributed in terms of the development of workshop materials and the design of workshop methods. Indigenous leaders moderated the discussions during the workshops to foster broad participation by community members. Indigenous leaders also led the interpretation of participant responses in light of the region's history and the local context of a given community. This helped ensure the validity of interpretations of participant perspectives.

For the activity on installation and repair of two-way radios, the team collaborated with indigenous allies who had experience in radio maintenance. The team spent considerable time in acquiring and testing equipment. Indigenous leaders collected data to make a diagnosis of the state of radio communications across the territory. On that basis, they identified relatively isolated communities and proposed a list of those communities as priorities to visit for purposes of radio installation. During visits to the communities, the team trained local youths in radio maintenance. The team provided the participants with repair manuals.

The archive compilation activity was successful in providing TIPNIS indigenous organizations with a key source of information to support their struggle for autonomy with regard to environmental governance. One of the key goals of the project was to remind communities mired in years of conflict of their history of collective mobilization that had yielded success in governance and management. Among the most valuable documents recovered in the effort are the minutes and decisions of indigenous organization meetings from 1988 forward. In those minutes are shared indigenous visions of territorial autonomy and strategies for political recognition and natural resource governance. The minutes thus clearly articulate a series of self-determined processes to pursue shared goals. The participatory mode of compiling the archive, in which indigenous leaders were crucial, and the focus on written indigenous history, instead of focusing on outside studies, made the resulting archive especially valuable to diverse organizations in the TIPNIS. Although it was not initially the main goal, the archive is also now publicly available 
(www.tipnisbolivia.org). It is listed in the national archives database in Bolivia and has been put forward as a participatory methodology to foster indigenous historical research.

\subsubsection{Participatory Data Collection for Governance of Dams in the Upper} Madeira Watershed

The Madeira River is the largest tributary of the Amazon, flowing from Bolivia into Brazil. The Madeira watershed encompasses significant fish diversity, notably among migratory species. Fish migration, and the livelihoods of communities reliant on fishing, are threatened by the construction of dams on the Madeira and its tributaries. The Government of Brazil has already constructed two hydroelectric dams on the Madeira River: Jirau, which is about $80 \mathrm{~km}$ from the border with Bolivia, and Santo Antonio, which is further downstream, about $7 \mathrm{~km}$ from the city of Porto Velho. In addition, Bolivia has planned the Cachuela Esperanza dam on the Beni River, a tributary of the Madeira River. Further, Bolivia and Brazil are jointly planning the Ribeirão binational dam on the Madeira River. The Santo Antonio and Jirau dams have already generated negative impacts on fisheries in the Upper Madera watershed $[89,90]$. The construction of additional dams will bring further impacts.

The goal of improving governance of dams and other infrastructure in the Amazon motivated the organization of a community of practice and learning (COP-L) among stakeholders in the Upper Madeira with organizational support from the University of Florida. The COP-L constitutes an organizational platform to facilitate learning from past experiences concerning the negative impacts of dams as a means to pursue more effective strategies for governance of infrastructure. The Upper Madeira COP-L encompasses 5 universities ( 3 in Bolivia, 1 in Brazil, and 1 in the US), 4 NGOs (all in Bolivia), 3 grassroots organizations (all in Bolivia), and 11 communities (7 in Bolivia and 4 in Brazil).

The Upper Madeira COP-L features the experiences and needs of communities impacted by dams. Local communities in Upper Madeira prioritize access to scientific knowledge about the impacts of dams, as well as building capacity in skills and strategies to confront proponents of dams. However, other stakeholders with that knowledge and know-how have limited access to those communities. The stakeholders of the Upper Madeira COP-L therefore pursued a cascading series of activities to strengthen ties and thereby pursue joint activities, shown in Figure 2. The Upper Madeira COP-L emerged and worked over a four-year period from 2017 to 2021. Its evolution can be traced via five phases: (1) emergence via initial meetings, (2) construction via learning among diverse stakeholders about the Upper Madeira, (3) planning via co-construction of an agenda of activities, (4) knowledge management via knowledge co-production, and (5) dissemination of co-produced knowledge for the application of findings in conservation strategies for improved governance of infrastructure. Crucial to this evolution was an emphasis on the inclusion of diverse stakeholders, processes to encourage broad participation, reflection on knowledge about past experiences, and trust-building exercises. 


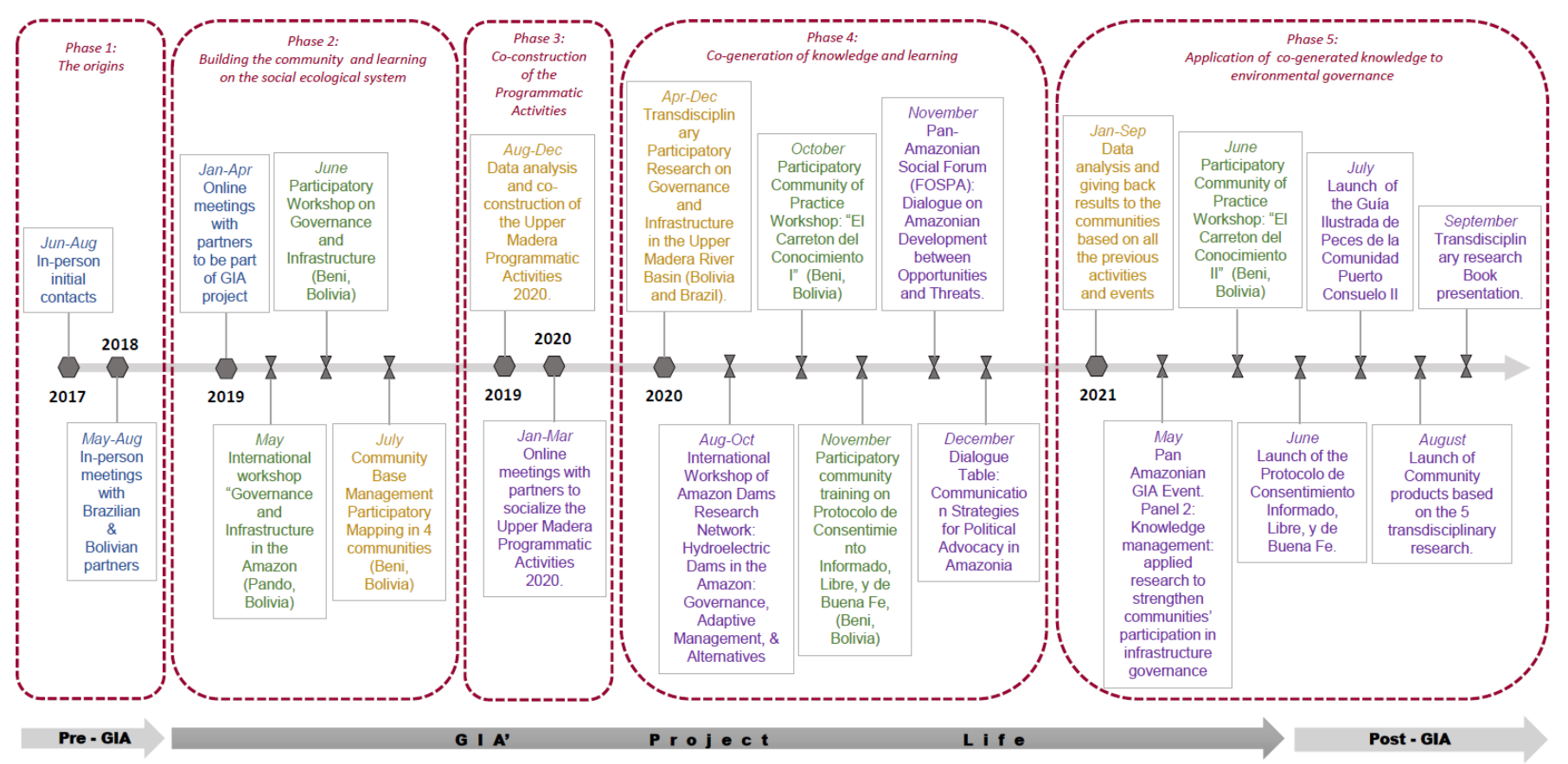

Colored key for activities: Blue $=$ Coordination; Purple $=$ On-line Events; Green $=$ In-person Events; Orange = Co-production of Knowledge

Figure 2. The Evolution of the Upper Madera Community of Practice and Learning, 2017-2021.

In this section, we focus on phase 4, during which the Upper Madeira COP-L pursued participatory research for the co-production of knowledge. In Section 4.3, we turn to phase 5, when the stakeholders engaged in the exchange of co-produced knowledge and planned actions to apply that knowledge. To be sure, the previous phases involved ample preparatory work. Phase 1 involved meetings for stakeholders to learn about each other and build trust, which began the process of defining the contours of knowledge funds and past experiences. Phase 2 included a series of meetings in which stakeholders deepened their knowledge exchange and participated in capacity-building activities, thus combining learning and practice. A focus on participatory forms of analysis, such as participatory mapping, helped identify key locations, communities, and other details to guide downstream research. Stakeholders thus organized joint visits to key communities to incorporate local perspectives about the impacts of dams into the COP-L.

In Phase 3, participants in the Upper Madeira COP-L engaged in a collective process of reflection on the knowledge shared in all of the previous activities. Partners reviewed interviews, event reports, maps, and training videos. Particular attention went to understanding the experiences and needs of local communities in Upper Madeira. Out of that process, the Upper Madeira COP-L identified priorities for joint learning and action. Those priorities were articulated in a program of activities. The Upper Madeira COP-L disseminated the program of activities broadly to stakeholders in the region to ensure they were aware and to encourage their participation. The program of activities, in turn, served as the basis for joint planning of activities among stakeholders.

Phase 4 focused on a participatory research program that was carefully orchestrated in a highly collaborative fashion by diverse stakeholders of the Upper Madeira COP-L. The priorities identified by local communities and grassroots organizations became research foci. University faculty from across Upper Madeira organized an applied science training course for students in regional universities. Those students then adopted priority topics defined by communities and grassroots organizations. Each student had an advisory committee composed of a faculty member at their home university, along with an NGO representative and one or more advisors from other universities. This made each research project highly participatory among the diverse stakeholders of the Upper Madeira COP-L and highlighted how communities and grassroots organizations drove the research agenda. University 
partners then worked closely with grassroots organizations on the field logistics, facilitating arrangements for field visits to communities for data collection. In this way, grassroots organizations oversaw the selection of field sites and coordinated access to communities for fieldwork.

Diverse COP-L stakeholders coordinated the details of the methods for data collection and traveled together to field sites. Students from diverse disciplines, ranging from biological sciences to engineering to law thus gathered data on a range of topics, including the perspectives of local communities on rights to free, prior, and informed consent (FPIC) during infrastructure planning, fish diversity in impacted rivers, and more. Regardless of the academic discipline of the topic, community members actively engaged in the coproduction of knowledge by offering their perspectives and supporting interpretations of the data. With the information in hand, the students conducted their analyses, wrote their undergraduate theses, and presented their projects in a scientific symposium at their home university.

The phase 4 activities not only generated co-produced knowledge made possible by a broadly participatory approach to the planning and conduct of research, but they also strengthened collaborative ties among diverse regional stakeholders. In particular, regional universities, grassroots organizations, and local communities gained valuable experience in working together for the common goal of co-producing knowledge on topics of shared interest. It is crucial that the collaborative experience focuses on knowledge coproduction via participatory research because all of the partners contributed and benefited in specific ways. Universities produced research valued by the regional society, as well as students with research experience, grassroots organizations became key brokers among other stakeholders as well as in terms of defining key details of the research conducted, and communities gained allies and contributed to knowledge production to serve downstream conservation and livelihood goals.

\subsection{Participatory Environmental Monitoring Systems}

In light of unfolding ecological change in the Amazon, environmental monitoring has become a priority for conservation. This has made participatory approaches to monitoring a priority, for local stakeholders often have knowledge and skills that complement those of outside researchers. Inclusive approaches can permit the construction of more robust monitoring systems. Information from participatory monitoring can in turn foster stakeholder support for policies and practices to better prepare for future disasters and mitigate environmental degradation. This section presents two experiences of participatory environmental monitoring: an effort to train people in forest extractivist communities to monitor forest health (Ribeiro, de Paula, and Selaya) and a network for risk reduction concerning extreme climatic events in the tri-national "MAP" frontier (Brown, Perales, and Rioja).

4.2.1. Participatory Monitoring of Forest Health in the Chico Mendes Extractive Reserve, Acre, Brazil

The western Brazilian state of Acre has a history of social mobilization to protect forests. The struggle of the rubber tappers there resulted in the creation of the Chico Mendes Extractive Reserve (CMER), an example of a model of sustainable use areas that combined conservation with local livelihoods [91,92]. A key issue in the management of the CMER and other extractive reserves has been the question of identifying new forestbased activities that generate income, especially as prices for rubber have declined over time [93]. The prospect of creating markets for forest carbon and other ecosystem services has called attention to community participation in payments for ecosystem services (PES) programs [94]. A key issue in community-based PES programs is that forests and other ecosystems must be monitored in order to quantify the services being conserved and thereby estimate their economic value [95]. 
Participatory monitoring of forests and other ecosystems has known technical requirements involving remote sensing and field-based methods of data collection [96]. However, there are issues that pose potential challenges to community participation in environmental monitoring [97]. Communities harbor social inequalities and conflicts, and community members have diverse perspectives on new income streams and PES.

Crucial in the agenda for advancing PES programs is the relationship between specific ecosystem services and broader ecosystem health. Conserving forest carbon is not only important for community livelihoods but also because carbon stocks are related to other ecosystem services. This requires engagement with communities for capacity building about ecosystem health as well as monitoring practices [98,99].

A project led by the Federal University of Acre with organizational support from the University of Florida therefore focused on community capacity building to support participatory monitoring of forest health in the CMER [97]. The project pursued a twostage approach: community workshops and engagement with the public school system in Acre. The community workshops focused on training community members in the CMER in skills with information technologies relevant to both job markets and forest monitoring. Engagement with the public school system focused on the development of curricular content on forest health for rural schools in forested areas. In both activities, a key objective was to align conservation objectives with stakeholder goals [97]. In the community workshops, the project team aligned capacity building for job skills with training for forest monitoring. In the rural public schools activity, the team sought to stimulate the use of forests by rural schools as laboratories for the development of curricular content on standard disciplines, including on the importance of forest health.

The community workshops involved a series of visits to CMER communities in multiple municipalities in Acre [97]. Initial workshops focused on capacity building with regard to forest ecology and botany. Subsequent workshops turned to methods in monitoring protocols and featured the use of information technologies. The team then worked alongside community members to establish permanent monitoring plots in the CMER. With the onset of forest monitoring, they jointly organized a workshop on the management and analysis of monitoring data. The team and communities then identified community leaders to lead the monitoring effort. The team supported those monitoring leaders, who were often young adults, in preparing to give workshops to disseminate what they had learned to other community members. Monitoring leaders thus gave dissemination workshops to other community members on forest health and the importance of forest monitoring.

The rural public school activity was not originally planned but arose as demand from community members who were participating in the workshops. Therefore, it complemented the workshop's activity in building the capacity of children and teenagers for future participatory forest monitoring [100]. The State Secretariat of Education and Sport of the Government of Acre approached the project team to contribute to the environmental education curriculum of the rural public school system. The team therefore worked with rural public school administrators to develop curriculum content on forest health for rural schools. The team then trained teachers, supervisors, and pedagogical coordinators from rural schools. This complemented the workshop's activity, which focused on adults, via outreach for children and teenagers from the 6th to the 12th grade. Because rural schools are often located in areas with forests, the curriculum features the use of the forest as a classroom for teaching the standard curriculum (e.g., math, sciences) while highlighting experiential learning about forest ecosystem services as indicators of forest health. The goal of the rural public school activity was thus to "open the eyes" of children and teenagers to see forests differently, as systems with services that merit monitoring for conservation and sustainable development. 
4.2.2. Networks for Environmental Monitoring and Emergency Management of Extreme Climatic Events

A key issue in the Amazon is that deforestation generates carbon emissions that help drive global climate change; in turn, global climate change manifests in the Amazon in the form of extreme climatic events [101]. In the southwestern Amazon, there has been an unprecedented series of floods and droughts [102-104]. In the tri-national "MAP" frontier, defined by Madre de Dios (Peru), Acre (Brazil), and Pando (Bolivia), floods transpired in 2006, 2009, 2010, 2011, 2012, 2013, 2014, and 2015, with records set in 2012 and 2015, while droughts occurred in 2005, 2010, and 2016 [104]. The floods were unprecedented for their frequency and severity. The 2012 flood affected 10 municipalities and some 143,000 people in the MAP frontier; the 2015 flood affected 9 municipalities and over 130,000 people [103]. Along the Acre River, some 1050 people were displaced in the town of Iñapari, with 4250 people in shelters in Cobija, 2500 in Brasiléia, and 1220 in Epitaciolândia [105]. Economic damage from the 2015 flood was extensive; estimates of property damage ranged from roughly $\$ 200$ million to $\$ 1$ billion [106]. During droughts, fires used to clear land for agriculture escaped control and burned 350,000 ha of forests in Acre in 2005, 120,000 in 2010, and 149,000 in 2016, with additional forest affected in Madre de Dios and Pando [104]. Fires cause extensive property damage, kill livestock, and cause significant health problems from the smoke. Fires in Acre caused an estimated \$307 million in damage during 2008-2012 [107]; the 2010 fires alone caused some \$240 million in damage in Acre [104].

The experiences of extreme climatic events constitute social traumas to affected populations [101]. A key challenge in the southwestern Amazon is that frontier areas far from centers of power receive less attention in times of disasters [106]. This set of circumstances thus led to calls for a tri-national response involving research in the frontier region [101]. Specifically, research required broad societal participation, where stakeholders would shift from being objects of study to contributors to knowledge and collective action.

One key societal response involved the MAP Initiative, a tri-national network of diverse stakeholders who began holding regular public forums for dialogue about action for participatory regional environmental planning. The experience of the 2005 drought followed by the 2006 flood prompted the emergence of the "Mini-MAP" working group on Risk Management (Mini-MAP Gestión de Riesgo, or MMGR), focusing on improving preparedness for extreme climatic events [102-104]. MMGR constituted a tri-national network of participants from regional universities, NGOs, local governments, and some national ministries, and featured the role of civil defense authorities including firefighters and militaries. MMGR began holding regular tri-national meetings to discuss common concerns, share information about extreme climatic events, and elaborate and adapt emergency management plans, especially by coordinating plans across national borders. It became clear that effective coordination would require creation and consolidation of environmental monitoring systems [102-104]. Over time, MMGR has broadened the participation of societal stakeholders in support of environmental monitoring as a means of improving governance of extreme climatic events [104].

MMGR partners conducted participatory dialogues with local stakeholders across the MAP frontier with the explicit goal of co-producing knowledge about the experiences of extreme events and their future risks [105]. Such dialogues went beyond interviewing by encouraging stakeholders to reflect on their experiences with regard to priorities for improving future preparedness. When combined with geographic information about critical locations where flooding had occurred, this provided the basis for planning for future emergency responses. Hence, by drawing on direct experiences and interpretations of those experiences by stakeholders, MMGR partners fostered co-produced knowledge as a basis for action in terms of flood response preparedness.

MMGR also pursued collaborative activities across national borders with diverse stakeholders to constitute an early warning system [102-104]. The Acre River flows out of Madre de Dios (Peru) along the border between Acre (Brazil) and Pando (Bolivia), so moni- 
toring upstream conditions is crucial to predicting flood risk downstream. MMGR partners thus pursued extensive institutional coordination between national weather services to acquire rainfall data, combined with hydrological data on the Acre River watershed and a digital elevation model (DEM) of the MAP frontier. This supported production of risk maps for flooding. After the 2012 flood, MMGR participants organized a joint expedition up the Acre River to install an environmental monitoring station some $70 \mathrm{~km}$ above Iñapari. That provided a crucial upriver data point for combining real-time data on precipitation and hydrology with DEM data in the early warning system. The monitoring system thus generated real-time data during major rainfall events on expected flood levels, areas subject to flooding, and time to evacuate.

MMGR partners broadened social participation by using the risk maps and other data products in related activities to support preparedness and emergency management planning [104]. Civil defense authorities made regular visits to communities in highrisk areas to discuss their experiences of extreme events and to coordinate emergency plans. During extreme events, MMGR partners made use of situation rooms in regional governments to coordinate emergency response using real-time data on precipitation and hydrological conditions from the early warning system.

With regard to droughts, MMGR supported environmental monitoring with other data sources from national governments and regional networks of monitoring stations. One key initiative has been to monitor fires using satellite imagery to identify "hot pixels" [107]. After the 2016 drought, MMGR was pursuing regular fire monitoring. In 2018, MMGR identified some 8000 hot pixels in the MAP frontier, with roughly 6500 in Acre, 1000 in Madre de Dios, and 500 in Pando. Fire monitoring is time-consuming due to the highly dynamic nature of fires, challenges with satellite images such as cloud cover, and the need to integrate data from multiple sensors. Methods to automate image processing and analysis have accelerated the process, though visual interpretation is still required to ensure accurate image classification [107]. Using a time series of governmental satellite image data from 1984 to 2018, MMGR partners identified some 526,000 ha of forests burned in Acre and confirmed spikes in key drought years [107]. MMGR partners, in turn, used university websites and social media platforms to disseminate updates on hot pixels to broad publics.

In addition to fire monitoring, in response to public concern, MMGR partners collaborated to install air quality monitoring stations across the MAP frontier [103,104]. Monitoring of particulate matter and related indicators of air quality reflects smoke concentrations that can pose threats to public health during major fires. Via online governmental portals, MMGR supports the real-time provision of air quality data to the public.

Key to broad participation in MMGR and its monitoring efforts have been the adaptation of communication networks, particularly during extreme climatic events. Civil defense authorities and other MMGR partners pursued a suite of communication strategies to inform local governments and the public, such as by issuing advisories about drought risk and bulletins about extreme events and evacuation routes [104]. Such communications often relied on the internet and cell service. During key events such as the 2005 fires and 2012 and 2015 floods, those communication systems often failed, precisely when they were most needed [104]. That prompted MMGR partners to experiment with alternative communication media, which incorporated additional stakeholders. The use of two-way radios among local radio operators proved much more resilient during extreme climatic events. That made radio operators valuable allies to civil defense authorities [104]. MMGR partners thus prioritized the installation of radios in rural schools and local towns to construct a multi-nodal communication network robust to heavy rainfall and other extreme weather. At the same time, MMGR partners formed social media groups via Whatsapp to intensify their ongoing communication for informational and planning purposes. Because of the widespread adoption of cell service and social media across the MAP frontier, the Whatsapp group was open to participation by a broader range of stakeholders than earlier MMGR partners. Participation in information sharing, advisories, and planning thus became broader in MMGR over time. 


\subsection{Innovative Models of Knowledge Exchange to Facilitate Collective Action for Conservation and Development}

Beyond participatory data collection and environmental monitoring, co-produced knowledge can be exchanged in various ways. This section discusses two innovative experiences with models of knowledge exchange in the Amazon: the "knowledge exchange train" in the MAP frontier (Mendoza, Pimentel, and Perz) and the "knowledge exchange cart" in the Upper Madeira watershed (Arteaga and Sanjinez). Both build on previous collaboration that co-produced knowledge, and both explicitly seek to leverage knowledge exchange for applied goals, such as environmental planning and governance of infrastructure.

\subsubsection{The Knowledge Exchange Train}

In the tri-national MAP frontier, new infrastructure is a key driver of change. The paving of the Interoceanic Highway in the 2000s fostered integration of the southwestern Amazon by facilitating urban population growth, economic activities such as gold mining and agribusiness, increased deforestation, and rising crime rates. The problems of regional integration drove increased societal demand for information as an input into participatory regional environmental planning. At the same time, it became more important for researchers to better understand the changes experienced by regional populations. This situation called for innovative models of knowledge exchange in a scaled-up format.

The "Knowledge Exchange Train" (KET) was developed to meet public demand for information about changes in the MAP frontier and to provide a platform for participatory regional environmental planning $[43,108]$. The basic model of the KET was to scale up knowledge exchange: instead of having one researcher or research team engage in knowledge exchange with stakeholders in one location, the KET proposed to bring together representatives of multiple research teams who would travel together to multiple communities and towns, making stops as if at train stations along a railway line, to hold workshops with diverse local stakeholders. The KET would thus scale-up knowledge exchange in terms of the research findings made available, the number of locations reached, and thus the stakeholders engaged. In turn, the KET would support participation by a broad array of stakeholders, who could share their experiences and perspectives with researchers.

In the MAP frontier, Mini-MAP Highways (MMH) organized a series of KETs over a period of roughly a decade, from 2006 to 2016, several with support from the University of Florida $[43,108]$. In each KET, MMH coordinators worked with local collaborators in various towns to identify locations for workshops. Local collaborators, in turn, identified key stakeholders and compiled lists of organizations and communities for invitations. $\mathrm{MMH}$ coordinators meanwhile reached out to partners in universities, NGOs, and government agencies conducting research in order to discuss research topics and constitute the KET team. With the KET workshop sites defined and the KET team designated, MMH coordinators engaged team members in the preparation of materials. Each KET team member produced a presentation for the workshops and a poster for discussion and as a product to be left with each community visited. MMH coordinators reviewed all presentations and posters for accessibility of content to diverse public audiences. The KET team then met to plan out the KET workshops in terms of time allocated to presentations, questions and answers, and poster sessions for discussions.

Between 2006 and 2016, MMH implemented five different KETs in the MAP frontier. Each KET involved 8-10 different research projects, visited 8-10 different towns, and reached 300-500 people, running from 7-14 days [43]. In each case, KET teams left posters with local communities, which permitted subsequent dissemination, whether via local schools or local governments. This increased the number of people reached by the KET team after the KET workshops.

The repetition of KETs over time in the MAP frontier has permitted the identification of challenges. First, rapid regional change meant that despite the KETs, as well as improved communication infrastructure, demand for knowledge has persisted over time. Second, the specifics of information needs have changed over time due to rapid shifts in stakeholder 
priorities. Third, in the MAP frontier, even though the impacts of the Interoceanic Highway and other change processes such as climate change might be shared across the region, there are local differences in stakeholders' preferences, not only about topics but the format of knowledge exchange. Fourth, social inequalities in access to information disadvantage rural communities, who are often harder to reach and who have difficulties in traveling to towns. This makes their inclusion particularly challenging if KET workshops occur in local towns. Fifth, KETs face challenges in sustaining engagement with local stakeholders, which can threaten the linkages from knowledge exchange to collective action.

The identification of challenges in KETs has in turn afforded adaptive management of KETs. The question of rapid change is difficult to manage. While KETs permit scaling up of knowledge exchange, online platforms such as social media offer a complement to in-person workshops, as by constituting online communities after workshops. On the changing priorities of stakeholders over time, $\mathrm{MMH}$ coordinators have more intensively engaged local collaborators on the selection of topics for KET workshops. This helps ensure that at least some topics are relevant to stakeholders, though other topics may also be important even if local people do not necessarily mention them. MMH coordinators also varied the topics on which the KET team presented from one workshop to another. This also helped open up more time for discussion. On the issue of diverse stakeholder constituencies, KET teams have varied KET workshop formats as well as topics [43]. MMH coordinators and KET team members found that early versions of KET workshops were too heavy on presentations, thus MMH coordinators shortened presentation times to open more space for audience participation via questions, dialogue, and reporting their own experiences. MMH coordinators also found that audiences varied widely among towns in terms of stakeholder composition and interests, thus KET teams varied workshop formats, ranging from presentations with questions and answers in some places to a focus on a poster fair with open discussions in other places. Similarly, there has been a tendency to move from presentations with words on screens toward presentations featuring visual images, maps, and videos. KET teams also innovated in presentation format by using interactive visualizations and question-answer discussions to modify visuals and other means of increasing audience participation when explaining key concepts or illustrating change processes. On the issue of social inequalities in the ability to travel to towns for participation in KET workshops, in later KETs, MMH coordinators specifically budgeted travel funds for a local collaborator or KET team member to go to rural communities and bring representatives to the workshops.

Perhaps the most important issue for the KET concerns the link from knowledge exchange to collective action. The KET offers three basic options in terms of its purpose. Originally, the KET was conceived as a form of large-scale knowledge exchange, with downstream knowledge dissemination by local collaborators. In this concept, the KET could permit collective action if stakeholders, notably local governments, chose to independently make use of the knowledge exchanged to implement new local policies. However, that was unsystematic and uncommon. A second version of the KET, therefore, saw the KET team use the workshops to identify local stakeholders interested in pursuing joint action in the future, whether with MMH coordinators or an individual research team. This was a more systematic way to leverage KET workshops into downstream action but still left the prospects for such action up to who participated and how the knowledge exchange unfolded. A third version of the KET, therefore, involved extensive planning before the workshops with key local stakeholders, notably local governments, on specific activities that could follow the KET workshop in their municipality. This involved using available knowledge to support municipal environmental planning. In this rendition of the KET, knowledge exchange was more programmatically linked to collective action.

\subsubsection{The Upper Madeira COP-L, Revisited: The Knowledge Exchange Cart}

Whereas we discussed the Upper Madeira COP-L's participatory data collection experience in Section 4.1, we return to that case here to discuss the innovative activities 
regarding knowledge exchange. In phase 5, the COP-L partners organized a modified version of the KET for communities in the Upper Madeira, called the "Knowledge Exchange Cart" (KEC, or El Carretón de Conocimiento).

The KEC incorporated multiple innovations concerning knowledge exchange as a form of PAR. First, the KEC leveraged the human resources and collaborative ties developed in the previous phases of the Upper Madeira COP-L. This helped constitute a team of committed professionals who had collaborated previously on shared activities with established goals. Second, the foci of the KEC derived directly from the priorities of local communities as communicated to grassroots organizations. This upheld the commitment to serve local stakeholder interests and leverage the brokering role of grassroots organizations. Third, the topical foci for the KEC not only included substantive information about the impacts of dams, but also featured priority conservation strategies to improve governance of dams, such as FPIC. Fourth, the KEC was designed around locations in the Upper Madeira to ensure local community participation in previous phases of activities of the COP-L. Therefore, the KECs were sited in places where the Governments of Bolivia and Brazil were planning dams, which were close to communities that would be affected and who participated actively in the Upper Madeira COP-L. KEC I thus occurred in Cachuela Esperanza, the site of the planned dam of the same name, and KEC II transpired in Guayarámirim, the site of the Ribeirão (Binational) dam. Fifth, planning for the KECs was impacted by the COVID-19 pandemic, which necessitated innovative practices. The planning process was highly participatory, with community members contributing suggestions to the design of in-person events to ensure the safety of the participants.

In each KEC, diverse stakeholders of the Upper Madeira COP-L came together for knowledge exchange to improve the governance of dams. Each KEC included participants from multiple communities, and professionals from multiple partner organizations gave talks on the impacts of dams as well as conservation strategies to improve governance of dams. The segment on FPIC featured a detailed discussion of FPIC protocols and how they can be constructed and implemented. It also highlighted communication strategies for COPL stakeholders, especially communities, grassroots organizations, and local governments, to obtain the attention of national governments and thereby increase their influence in the infrastructure planning process. This can support political advocacy for FPIC and other strategies to improve the planning process and perhaps stop ill-conceived dams.

We note that the KECs were one platform among others pursued by the Upper Madeira COP-L with a focus on knowledge exchange. Stakeholders of the Upper Madeira COP-L also participated in virtual workshops organized by the Amazon Dams Network (ADN), the Pan-Amazonian Social Forum (FOSPA), and the Governance and Infrastructure in the Amazon (GIA) project, where they gave presentations and interacted with peers about lessons learned from their experiences about strategies to improve governance of dams. In those events, the Upper Madeira COP-L stood out as a model for networking that features the active participation of grassroots stakeholders in planning, capacity building, research as co-production of knowledge, knowledge exchange, and collective action.

In the KECs and other events, the Upper Madeira COP-L distributed materials to the participating stakeholders. The materials included both substantive content, such as a guide to the identification of fish in the Upper Madeira watershed and the results from student theses, as well as strategic content, such as protocols for FPIC and communication strategies for political advocacy. The substantive products reflected the co-produced knowledge of the Upper Madeira COP-L in a form accessible to local communities and grassroots organizations, whereas the strategic products provided guidelines for collective action. Both products reflected the collaborative process among stakeholders in the Upper Madeira COP-L and served to empower local and grassroots stakeholders with knowledge and strategies to pursue their goals.

Overall, the Upper Madeira COP-L generated numerous products. It held some 10 in-person events and 20 virtual events, which collectively reached roughly 1200 people. Along the way, COP-L partners conducted some 150 interviews as part of participatory 
research activities. Consequently, the Upper Madeira COP-L generated over 50 products with substantive and strategic content, including 20 videos from community members.

In turn, the COP-L facilitated the planning of collective action for the governance of infrastructure in the Upper Madeira. The positive experiences of regional universities with the PAR approach have them considering how to broaden their use of PAR in more of their training programs. The COP-L birthed a working group on FPIC protocols that are beginning to work with other communities in Bolivia and Brazil, as well as in Peru and Colombia. The fish guide also led to the creation of a working group that is engaging Fishers' Associations and tourism operations about impacts of dams by way of forging broader alliances against dams in the Upper Madeira. The COP-L provided all of its products to the Binational Committee working across the Bolivia-Brazil border to resist new dams. The Binational Committee is leveraging its ties to municipal and departmental governments to use the products in its advocacy against dams due to their negative impacts.

\subsection{Comparative Analysis}

We conclude our discussion of the findings by summarizing the experiences overall in light of the framework presented earlier. While each case study is an experience in its own right, different approaches to PAR can all be discussed in light of shared PAR principles. We focus first on the PAR framework, which was organized around a suite of six stages in the research process. Table 1 presents summary comments on each of the study cases reported, noting the key activities. Of particular interest in the content of Table 1 are the cases and stages where stakeholders led activities in different stages (i.e., the "participation" principle in PAR) and the extent to which the PAR process led to applications in the final stage (i.e., the "action" principle in PAR).

We therefore drew on Table 1 to conduct a basic analysis of the degree to which stakeholders led activities in the six stages, shown in Table 2. We consider stakeholder leadership to be "high" in cases where stakeholders clearly defined and/or implemented the activities noted, "medium" where researchers played a lead role but stakeholders had supporting input, and "low" where stakeholders had no input. Table 2 thus presents the designations and comments on those designations. In the six experiences reported, all of the designations were high or medium across all of the stages. Stakeholders led in three of the six cases in problem definition, two of the cases in proposal development, four of the cases in data collection, one of the cases in analysis and conclusions, five of the cases in knowledge exchange, and one of the cases in applications. In terms of the cases themselves, stakeholder contributions were high in five stages in MMGR, three stages in the TIPNIS and Upper Madera, two stages in Cauca/Colombia and the CMER, and one in MMH. This is not to suggest that one experience is somehow better than another by being more participatory, because the models are all distinct, and they indicate stakeholder leadership in different stages. These findings are best interpreted as indicating that different models of PAR among the cases reported highlight stakeholder participation at different moments and in different ways. We note that the MMGR is also the longest-standing effort, as a network rather than a single project, which may help explain its highly participatory experience. Consequently, we would expect to see increases in stakeholder leadership as other PAR efforts mature. 
Table 1. Participatory action research methods employed by stage of the research process, case studies in the western Amazon.

\begin{tabular}{|c|c|c|c|c|c|c|}
\hline Study Case & $\begin{array}{l}\text { Stage 1: } \\
\text { Problem } \\
\text { Definition }\end{array}$ & $\begin{array}{l}\text { Stage 2: } \\
\text { Proposal } \\
\text { Development, } \\
\text { Methods }\end{array}$ & $\begin{array}{l}\text { Stage 3: Data } \\
\text { Collection, } \\
\text { Compilation }\end{array}$ & $\begin{array}{c}\text { Stage 4: Data } \\
\text { Analysis, } \\
\text { Conclusions }\end{array}$ & $\begin{array}{l}\text { Stage 5: } \\
\text { Knowledge } \\
\text { Exchange }\end{array}$ & $\begin{array}{c}\text { Stage 6: } \\
\text { Applications of } \\
\text { Knowledge }\end{array}$ \\
\hline $\begin{array}{l}\text { Resilience } \\
\text { among } \\
\text { Traditional } \\
\text { Peoples, Valle } \\
\text { and Cauca, } \\
\text { Colombia }\end{array}$ & $\begin{array}{l}\text { Planning } \\
\text { priorities of } \\
\text { traditional } \\
\text { peoples }\end{array}$ & $\begin{array}{l}\text { Workshops on } \\
\text { relational } \\
\text { ontologies, } \\
\text { practices }\end{array}$ & $\begin{array}{c}\text { Survey } \\
\text { responses on } \\
\text { practices in use }\end{array}$ & $\begin{array}{l}\text { Workshops on } \\
\text { findings of } \\
\text { traditional } \\
\text { practices }\end{array}$ & $\begin{array}{l}\text { Return of } \\
\text { findings to } \\
\text { communities } \\
\text { overseen by } \\
\text { community } \\
\text { leaders }\end{array}$ & $\begin{array}{l}\text { Application of } \\
\text { findings to } \\
\text { territorial } \\
\text { planning for } \\
\text { resilience }\end{array}$ \\
\hline $\begin{array}{l}\text { Compilation of } \\
\text { archive of } \\
\text { indigenous } \\
\text { governance, } \\
\text { TIPNIS, Bolivia }\end{array}$ & $\begin{array}{l}\text { Indigenous } \\
\text { priority on } \\
\text { recovering } \\
\text { history and } \\
\text { repairing ties } \\
\text { among } \\
\text { communities }\end{array}$ & $\begin{array}{c}\text { Definition of } \\
\text { three key } \\
\text { activities: } \\
\text { compile archive, } \\
\text { visits to } \\
\text { communities, } \\
\text { installation of } \\
\text { radios }\end{array}$ & $\begin{array}{c}\text { Indigenous } \\
\text { leaders } \\
\text { provided key } \\
\text { documents for } \\
\text { archive, } \\
\text { oversaw visits } \\
\text { and installations }\end{array}$ & $\begin{array}{l}\text { Indigenous } \\
\text { leaders } \\
\text { interpreted key } \\
\text { documents for } \\
\text { archive }\end{array}$ & $\begin{array}{l}\text { Distribution of } \\
\text { archive in print } \\
\text { and online to } \\
\text { indigenous } \\
\text { communities }\end{array}$ & $\begin{array}{l}\text { Interactions } \\
\text { among } \\
\text { communities }\end{array}$ \\
\hline $\begin{array}{c}\text { COP-L on the } \\
\text { governance of } \\
\text { infrastructure, } \\
\text { Upper Madera, } \\
\text { Bolivia, and } \\
\text { Brazil }\end{array}$ & $\begin{array}{c}\text { Communities } \\
\text { and grassroots } \\
\text { organizations } \\
\text { defined research } \\
\text { priorities }\end{array}$ & $\begin{array}{c}\text { Grassroots } \\
\text { organizations } \\
\text { brokered field } \\
\text { logistics } \\
\text { between } \\
\text { universities and } \\
\text { communities }\end{array}$ & $\begin{array}{l}\text { Universities and } \\
\text { others collected } \\
\text { data, featured } \\
\text { experiences and } \\
\text { perspectives of } \\
\text { communities }\end{array}$ & $\begin{array}{l}\text { Analysis } \\
\text { featured } \\
\text { community } \\
\text { perspectives }\end{array}$ & $\begin{array}{l}\text { Knowledge } \\
\text { exchange cart, } \\
\text { dissemination of } \\
\text { results with the } \\
\text { community and } \\
\text { grassroots input, } \\
\text { led to proposals } \\
\text { for applications }\end{array}$ & $\begin{array}{c}\text { Results led } \\
\text { COP-L partners } \\
\text { to define } \\
\text { strategic } \\
\text { priorities for } \\
\text { collective action }\end{array}$ \\
\hline $\begin{array}{l}\text { Monitoring of } \\
\text { Forest Health in } \\
\text { the CMER, Acre, } \\
\text { Brazil }\end{array}$ & $\begin{array}{l}\text { Alignment of } \\
\text { researcher and } \\
\text { community } \\
\text { conservation } \\
\text { and } \\
\text { development } \\
\text { goals }\end{array}$ & $\begin{array}{c}\text { Focus on } \\
\text { capacity } \\
\text { building about } \\
\text { forest health and } \\
\text { skills relevant to } \\
\text { job markets and } \\
\text { environmental } \\
\text { monitoring }\end{array}$ & $\begin{array}{c}\text { Joint } \\
\text { implementation } \\
\text { of permanent } \\
\text { forest } \\
\text { monitoring } \\
\text { plots, use of } \\
\text { forests as } \\
\text { experiential } \\
\text { learning } \\
\text { classrooms }\end{array}$ & $\begin{array}{l}\text { Community } \\
\text { monitoring } \\
\text { leaders conduct } \\
\text { analyses of } \\
\text { monitoring data }\end{array}$ & $\begin{array}{c}\text { Community } \\
\text { monitoring } \\
\text { leaders gave } \\
\text { dissemination } \\
\text { workshops to } \\
\text { their } \\
\text { communities on } \\
\text { forest health } \\
\text { and monitoring }\end{array}$ & $\begin{array}{l}\text { Community } \\
\text { monitoring } \\
\text { leaders applying } \\
\text { knowledge } \\
\text { about forest } \\
\text { health and } \\
\text { monitoring }\end{array}$ \\
\hline $\begin{array}{c}\text { Mini-MAP Risk } \\
\text { Management, } \\
\text { tri-national } \\
\text { MAP frontier, } \\
\text { Bolivia-Brazil- } \\
\text { Peru }\end{array}$ & $\begin{array}{l}\text { Broad regional } \\
\text { social trauma } \\
\text { from experience } \\
\text { of extreme } \\
\text { climatic events; } \\
\text { demand for } \\
\text { regional } \\
\text { response }\end{array}$ & $\begin{array}{l}\text { Civil defense } \\
\text { leadership in } \\
\text { activities to plan } \\
\text { and implement } \\
\text { coordinated } \\
\text { preparedness } \\
\text { and emergency } \\
\text { management } \\
\text { response }\end{array}$ & $\begin{array}{l}\text { Institutional } \\
\text { coordination to } \\
\text { establish early } \\
\text { warning } \\
\text { systems for } \\
\text { floods, } \\
\text { monitoring } \\
\text { systems for fires } \\
\text { and air quality }\end{array}$ & $\begin{array}{l}\text { Institutional } \\
\text { coordination for } \\
\text { analysis of } \\
\text { climate data for } \\
\text { emergency } \\
\text { response }\end{array}$ & $\begin{array}{c}\text { Institutional } \\
\text { coordination } \\
\text { across national } \\
\text { boundaries, the } \\
\text { establishment of } \\
\text { multiple } \\
\text { communication } \\
\text { networks with } \\
\text { local } \\
\text { stakeholders for } \\
\text { monitoring and } \\
\text { emergency } \\
\text { response }\end{array}$ & $\begin{array}{l}\text { Use of early } \\
\text { earning, fire } \\
\text { monitoring data } \\
\text { in preparedness } \\
\text { planning and } \\
\text { emergency } \\
\text { management } \\
\text { responses } \\
\text { during extreme } \\
\text { climatic events }\end{array}$ \\
\hline $\begin{array}{c}\text { Mini-MAP } \\
\text { Highways, MAP } \\
\text { frontier, Bolivia- } \\
\text { Brazil-Peru }\end{array}$ & $\begin{array}{c}\text { Multiple } \\
\text { institutions with } \\
\text { diverse research } \\
\text { activities in } \\
\text { response to } \\
\text { societal } \\
\text { concerns about } \\
\text { rapid change }\end{array}$ & $\begin{array}{c}\text { Diverse } \\
\text { processes for the } \\
\text { design of } \\
\text { research projects } \\
\text { as a contribution } \\
\text { to knowledge } \\
\text { exchange }\end{array}$ & $\begin{array}{l}\text { Diverse } \\
\text { methods for } \\
\text { collection of } \\
\text { data for } \\
\text { knowledge } \\
\text { exchange }\end{array}$ & $\begin{array}{l}\text { Initial analysis } \\
\text { of project } \\
\text { findings by } \\
\text { researchers; } \\
\text { complemented } \\
\text { by perspectives } \\
\text { of stakeholders } \\
\text { at knowledge } \\
\text { exchange } \\
\text { workshops }\end{array}$ & $\begin{array}{l}\text { Knowledge } \\
\text { exchange train; } \\
\text { workshops with } \\
\text { multiple } \\
\text { projects in } \\
\text { multiple towns } \\
\text { to scale up } \\
\text { knowledge } \\
\text { exchange }\end{array}$ & $\begin{array}{l}\text { Spontaneous or } \\
\text { planned } \\
\text { application of } \\
\text { knowledge } \\
\text { exchanged } \\
\text { during } \\
\text { workshops; } \\
\text { downstream } \\
\text { research or local } \\
\text { environmental } \\
\text { planning }\end{array}$ \\
\hline
\end{tabular}


Table 2. Analysis of the degree of leadership in contributions by stakeholders, participatory action research methods, by stage of the research process, case studies in the western Amazon.

\begin{tabular}{|c|c|c|c|c|c|c|}
\hline Study Case & $\begin{array}{c}\text { Stage 1: } \\
\text { Problem } \\
\text { Definition }\end{array}$ & $\begin{array}{c}\text { Stage 2: } \\
\text { Proposal } \\
\text { Development, } \\
\text { Methods }\end{array}$ & $\begin{array}{c}\text { Stage 3: Data } \\
\text { Collection, } \\
\text { Compilation }\end{array}$ & $\begin{array}{c}\text { Stage 4: Data } \\
\text { Analysis, } \\
\text { Conclusions }\end{array}$ & $\begin{array}{c}\text { Stage 5: } \\
\text { Knowledge } \\
\text { Exchange }\end{array}$ & $\begin{array}{c}\text { Stage 6: } \\
\text { Applications of } \\
\text { Knowledge }\end{array}$ \\
\hline $\begin{array}{c}\text { Resilience } \\
\text { among } \\
\text { Traditional } \\
\text { Peoples, Cauca, } \\
\text { Colombia }\end{array}$ & $\begin{array}{l}\text { High; } \\
\text { communities } \\
\text { defined the } \\
\text { research } \\
\text { priorities as } \\
\text { resilience to } \\
\text { disasters }\end{array}$ & $\begin{array}{c}\text { Medium; } \\
\text { stakeholders } \\
\text { and researchers } \\
\text { contributed } \\
\text { elements to the } \\
\text { resilience } \\
\text { evaluation }\end{array}$ & $\begin{array}{c}\text { Medium; } \\
\text { researchers } \\
\text { gathered data } \\
\text { via surveys with } \\
\text { community } \\
\text { members }\end{array}$ & $\begin{array}{l}\text { Medium; } \\
\text { researchers } \\
\text { conducted } \\
\text { analysis and } \\
\text { identified } \\
\text { tentative } \\
\text { conclusions } \\
\text { based on } \\
\text { stakeholder } \\
\text { contributions to } \\
\text { indicators }\end{array}$ & $\begin{array}{c}\text { High; } \\
\text { researchers } \\
\text { returned } \\
\text { findings via } \\
\text { workshops in } \\
\text { which } \\
\text { stakeholders } \\
\text { provided their } \\
\text { perspectives in } \\
\text { light of } \\
\text { relational } \\
\text { ontologies }\end{array}$ & $\begin{array}{l}\text { Medium; } \\
\text { stakeholder } \\
\text { workshops to } \\
\text { return data were } \\
\text { also planning } \\
\text { workshops for } \\
\text { community } \\
\text { actions on } \\
\text { traditional } \\
\text { practices and } \\
\text { resilience }\end{array}$ \\
\hline $\begin{array}{l}\text { Compilation of } \\
\text { archive of } \\
\text { indigenous } \\
\text { governance, } \\
\text { TIPNIS, Bolivia }\end{array}$ & $\begin{array}{c}\text { High; } \\
\text { indigenous } \\
\text { organizations } \\
\text { set priorities on } \\
\text { recovering } \\
\text { histories of } \\
\text { effective } \\
\text { governance }\end{array}$ & $\begin{array}{c}\text { High; } \\
\text { indigenous } \\
\text { organizations } \\
\text { prioritized three } \\
\text { specific types of } \\
\text { activities }\end{array}$ & $\begin{array}{c}\text { High; } \\
\text { community } \\
\text { leaders } \\
\text { provided crucial } \\
\text { documents and } \\
\text { information, } \\
\text { along with } \\
\text { historical } \\
\text { context about } \\
\text { their importance }\end{array}$ & $\begin{array}{l}\text { Medium; project } \\
\text { consultants } \\
\text { wrote up the } \\
\text { analysis, based } \\
\text { heavily on } \\
\text { insights from } \\
\text { community } \\
\text { leaders }\end{array}$ & $\begin{array}{c}\text { Medium; } \\
\text { researchers } \\
\text { provided } \\
\text { communities } \\
\text { with archives } \\
\text { and user } \\
\text { manuals, as well } \\
\text { as improved } \\
\text { communications } \\
\text { media }\end{array}$ & $\begin{array}{c}\text { Medium; } \\
\text { outputs of } \\
\text { activities } \\
\text { (archives, radios, } \\
\text { visits about } \\
\text { IRNT) created } \\
\text { conditions for } \\
\text { collective action } \\
\text { in the TIPNIS }\end{array}$ \\
\hline $\begin{array}{l}\text { COP-L on the } \\
\text { governance of } \\
\text { infrastructure, } \\
\text { Upper Madera, } \\
\text { Bolivia, and } \\
\text { Brazil }\end{array}$ & $\begin{array}{c}\text { High; } \\
\text { communities } \\
\text { and grassroots } \\
\text { organizations } \\
\text { identified } \\
\text { knowledge } \\
\text { needs }\end{array}$ & $\begin{array}{c}\text { Medium; } \\
\text { grassroots } \\
\text { organizations } \\
\text { brokered with } \\
\text { communities for } \\
\text { field logistics, } \\
\text { universities } \\
\text { designed } \\
\text { specific methods }\end{array}$ & $\begin{array}{l}\text { High; diverse } \\
\text { stakeholders } \\
\text { collaborated in } \\
\text { multiple aspects } \\
\text { of the fieldwork }\end{array}$ & $\begin{array}{l}\text { Medium; } \\
\text { researchers } \\
\text { conducted } \\
\text { analyses and } \\
\text { wrote up } \\
\text { conclusions } \\
\text { based on } \\
\text { perspectives of } \\
\text { communities } \\
\text { and grassroots } \\
\text { organizations }\end{array}$ & $\begin{array}{c}\text { High; } \\
\text { researchers } \\
\text { returned } \\
\text { findings in KEC } \\
\text { workshops } \\
\text { designed for } \\
\text { stakeholders to } \\
\text { share their } \\
\text { perspectives }\end{array}$ & $\begin{array}{l}\text { Medium; joint } \\
\text { activities and } \\
\text { research outputs } \\
\text { created } \\
\text { conditions for } \\
\text { collective action } \\
\text { to improve } \\
\text { governance of } \\
\text { dams }\end{array}$ \\
\hline $\begin{array}{l}\text { Monitoring of } \\
\text { Forest Health in } \\
\text { the CMER, Acre, } \\
\text { Brazil }\end{array}$ & $\begin{array}{l}\text { Medium; } \\
\text { researchers } \\
\text { aligned project } \\
\text { priorities with } \\
\text { community } \\
\text { needs }\end{array}$ & $\begin{array}{l}\text { Medium; } \\
\text { researchers } \\
\text { designed } \\
\text { monitoring } \\
\text { protocols that } \\
\text { highlighted } \\
\text { skills acquisition } \\
\text { prioritized by } \\
\text { community } \\
\text { members }\end{array}$ & $\begin{array}{c}\text { High; } \\
\text { researchers } \\
\text { trained } \\
\text { monitoring } \\
\text { leaders who } \\
\text { collected and } \\
\text { managed data } \\
\text { on forest health }\end{array}$ & $\begin{array}{l}\text { Medium; } \\
\text { researchers and } \\
\text { monitoring } \\
\text { leaders } \\
\text { conducted } \\
\text { analyses }\end{array}$ & $\begin{array}{c}\text { High; } \\
\text { monitoring } \\
\text { leaders led } \\
\text { dissemination } \\
\text { workshops with } \\
\text { stakeholder } \\
\text { communities on } \\
\text { forest health } \\
\text { and forest } \\
\text { monitoring }\end{array}$ & $\begin{array}{c}\text { Medium; } \\
\text { capacity } \\
\text { building and } \\
\text { stakeholder-led } \\
\text { workshops } \\
\text { created } \\
\text { conditions for } \\
\text { community } \\
\text { forest } \\
\text { monitoring }\end{array}$ \\
\hline $\begin{array}{c}\text { Mini-MAP Risk } \\
\text { Management, } \\
\text { tri-national } \\
\text { MAP frontier, } \\
\text { Bolivia-Brazil- } \\
\text { Peru }\end{array}$ & $\begin{array}{l}\text { Medium; } \\
\text { general societal } \\
\text { demand to } \\
\text { conduct } \\
\text { something to } \\
\text { respond to } \\
\text { extreme climatic } \\
\text { events }\end{array}$ & $\begin{array}{l}\text { High; diverse } \\
\text { stakeholders } \\
\text { developed } \\
\text { coordinated } \\
\text { emergency } \\
\text { response plans }\end{array}$ & $\begin{array}{l}\text { High; diverse } \\
\text { stakeholders } \\
\text { created and } \\
\text { managed } \\
\text { monitoring } \\
\text { systems for } \\
\text { precipitation, } \\
\text { floods, fires, and } \\
\text { air quality }\end{array}$ & $\begin{array}{l}\text { High; diverse } \\
\text { stakeholders } \\
\text { jointly } \\
\text { conducted } \\
\text { analyses of } \\
\text { climatic data, } \\
\text { especially } \\
\text { during extreme } \\
\text { climatic events }\end{array}$ & $\begin{array}{l}\text { High; diverse } \\
\text { stakeholders } \\
\text { regularly shared } \\
\text { information } \\
\text { across national } \\
\text { boundaries for } \\
\text { coordination of } \\
\text { emergency } \\
\text { response }\end{array}$ & $\begin{array}{c}\text { High; } \\
\text { stakeholders } \\
\text { implemented } \\
\text { early warning } \\
\text { systems and } \\
\text { emergency } \\
\text { response } \\
\text { management } \\
\text { plans }\end{array}$ \\
\hline $\begin{array}{l}\text { Mini-MAP } \\
\text { Highways, MAP } \\
\text { frontier, Bolivia- } \\
\text { Brazil-Peru }\end{array}$ & $\begin{array}{l}\text { Medium; } \\
\text { general societal } \\
\text { demand to } \\
\text { conduct } \\
\text { something to } \\
\text { respond to } \\
\text { highway paving }\end{array}$ & $\begin{array}{l}\text { Medium; the } \\
\text { KET } \\
\text { encompassed } \\
\text { teams with } \\
\text { diverse } \\
\text { methods, and } \\
\text { workshops had } \\
\text { varying } \\
\text { exchange } \\
\text { modalities }\end{array}$ & $\begin{array}{l}\text { Medium; project } \\
\text { teams presented } \\
\text { findings, and } \\
\text { stakeholders } \\
\text { related their } \\
\text { experiences }\end{array}$ & $\begin{array}{l}\text { Medium; } \\
\text { researchers } \\
\text { reported results } \\
\text { of analyses, but } \\
\text { stakeholders } \\
\text { also interpreted } \\
\text { findings in light } \\
\text { of their own } \\
\text { experiences }\end{array}$ & $\begin{array}{c}\text { High; } \\
\text { researchers and } \\
\text { stakeholders } \\
\text { routinely } \\
\text { exchanged } \\
\text { knowledge in } \\
\text { KET workshops }\end{array}$ & $\begin{array}{l}\text { Medium; KETs } \\
\text { sometimes } \\
\text { served as inputs } \\
\text { for local } \\
\text { governments to } \\
\text { implement } \\
\text { territorial } \\
\text { environmental } \\
\text { plans }\end{array}$ \\
\hline
\end{tabular}


Table 2 also focuses on the issue of applications of knowledge to collective action. As was just noted, most cases obtained a "medium" designation in that they created the conditions for collective action, often by reaching the moment for reflection on implications of findings to support planning for action. The MMGR was the one case where knowledge was applied beyond reflection and planning as the network developed, implemented, and adapted early warning systems and emergency response management plans. This reflects the MMGR's longer-term existence than the other cases reported. This leaves open the possibility that other cases, with time, can also achieve the "high" designation in terms of applications of knowledge to action.

\section{Discussion}

The foregoing case studies show that PAR has been practiced in distinct but innovative ways for conservation and development in the western Amazon. Whether via participatory data collection, creation of monitoring systems, or knowledge exchange, specific PAR practices can support sustainability and related goals. In each case study, teams or networks engaged in PAR activities that facilitated stakeholder participation, whether via leadership or via collaborative contributions with researchers, at every stage across the research process. In that regard, the experiences reported constitute valuable models of PAR for conservation and development in a rapidly changing context such as the Amazon. In addition, the case studies reported also pursued applications of knowledge from participatory research, at least by creating conditions for collective action, as via planning activities. However, the longest-existing case also showed that with more time, creating conditions and planning can lead to implementation.

The cases from the Amazon also constitute a diverse suite of experiences with regard to previous work on topics related to PAR that we featured in our background review, ranging from trans-disciplinarity to knowledge co-production. While it seems evident that most or all of the cases exhibit some of those traditions, other bodies of work are not as salient in most experiences. Broader approaches to PAR, such as trans-disciplinarity, democratization of knowledge, and knowledge co-production, are evident in every case reported insofar as they span disciplines and incorporate diverse stakeholders in collaborative activities of collecting and interpreting information. Knowledge exchange is also evident to some degree in all of the cases, though it is highlighted in some (MMH via the KETs and the Upper Madeira via the KECs). Citizen science was similarly evident in most cases but especially salient in a few, notably those featuring participatory monitoring systems (the CMER and the MMGR). Cases that focused specifically on local communities, grassroots organizations and/or indigenous groups tended to highlight traditions such as TEK and decolonization (Cauca/Colombia, the TIPNIS, and the Upper Madeira). In sum, the Amazon case studies are highly responsive to multiple traditions of thought and action related to PAR. As such, they constitute valuable models for replication and adaptation elsewhere.

In the process of discussing the PAR cases from the Amazon, some key issues in pursuing PAR also arose. One concerns the importance of efforts to build trust between researchers and stakeholders, as well as among diverse stakeholders. In some cases, previous collaboration facilitated trust-building (e.g., Cauca/Colombia, TIPNIS). In others, the process of building trust required time (e.g., CMER) and/or structured events to exchange perspectives and experiences (e.g., Upper Madeira) to identify common interests. Finally, in some cases, external crises imposed demands on stakeholders that motivated them to engage (e.g., MMGR, MMH).

Another issue that arose among the cases reported concerned the challenge of communication. When outside researchers seek to work with local stakeholders, especially those who reside in rural areas or along rivers, in-person meetings can be logistically complicated and expensive to arrange. However, reliance on other communication media poses limitations on collaboration. Further, in cases such as the MMGR, extreme climatic events can significantly undermine communication, especially when it is urgent and time-sensitive. Taken together, the cases reported suggest that PAR requires a multi-pronged approach to 
communication to support stakeholder leadership, trust-building, and progress on activities. While in-person meetings are ideal, the use of two-way radios, cell networks with social media (e.g., Whatsapp), and the internet are all important. The key then is to inculcate standardized practices when communication via one medium becomes unavailable.

Beyond those issues are other challenges to PAR, whether in the Amazon or elsewhere. One challenge concerns new or emergent forms of the politicization of knowledge related to conservation and development. Whether via "fake news," distrust of expertise, or relativism about knowledge claims, the politicization of knowledge poses threats to PAR for sustainability $[109,110]$. Because of social inequalities and political contestation over many conservation and development issues in the Amazon and other regions, knowledge claims by researchers and subaltern groups alike may be countered by various tactics to distract, distort and otherwise undermine. Whether concerning climate change, infrastructure projects, or management plans for protected areas and indigenous lands, knowledge claims based on methodologically sound empirics and legal precedents may be attacked.

Another challenge concerns the COVID-19 pandemic. Whereas PAR seeks to valorize and prioritize the contributions of stakeholders in research and action, the particular vulnerability of many stakeholders such as indigenous groups to outside diseases constitutes a significant threat to their well-being and thus constitutes a severe constraint on collaboration. In some cases, such as the MMGR, COVID compounded the threats posed by drivers of change, such as extreme climatic events, which drive people indoors where COVID-19 transmission becomes more likely. In other cases, such as the Upper Madeira and the CMER experiences, COVID-19 imposed changes in communication practices and the format of events. COVID-19 thus poses challenges to collaborative practice for PAR and creativity in innovating in the use of communications media to sustain joint activities and trust. The use of online communication platforms for virtual meetings has become crucial, as well as changes in the timing of meetings to avoid days and times of heavy internet traffic to permit participation by stakeholders with limited bandwidth. Whereas the pursuit of effective governance for conservation and development as means to achieve sustainability requires PAR, the practice of PAR requires ongoing innovation, evident in the cases presented here, as well as innovations in those PAR models in light of new challenges such as COVID-19.

Author Contributions: Contributions of case studies: Cauca/Colombia-M.C.R.P., TIPNIS-A.B.F., Upper Madeira-M.A. and L.C.S.L., CMER-S.C.R., N.G.S.G., and Y.A.P.d.P., MMGR-I.F.B., L.M.P.Y, and G.R.-B., MMH-E.R.H.M., A.d.S.P. and S.G.P.; writing—original draft preparation: S.G.P., M.A., A.B.F., G.R.-B.; writing-review and editing: S.G.P., M.A., A.B.F., S.C.R., N.G.S.G., Y.A.P.d.P. and G.R.-B. All authors have read and agreed to the published version of the manuscript.

Funding: One or more of the case studies reported were funded by the Gordon and Betty Moore Foundation (Grant \#7715), the US Agency for International Development (Cooperative Agreements RLA-A-00-06-00071-00, 512-A-00-08-00003-00, AID-OAA-A-11-00060, and AID-OAA-A-11-00012), the US National Science Foundation (Grants HSD 0527511 and CNH 1114924), the Inter-American Institute for Global Change Research (Grant SGP-HW 016), and the Inter-American Foundation.

Institutional Review Board Statement: Research for the applicable cases reported was conducted according to the guidelines of the Declaration of Helsinki, and approved by the Institutional Review Board (or Ethics Committee) of the University of Florida, protocols IRB201900376, approved 19 July 2019 for the Upper Madeira, IRB201702702, approved 7 December 2017 for the TIPNIS, IRB20201770, approved 30 October 2020 for Cauca/Colombia. The other cases were exempt due to not involving human subjects research.

Informed Consent Statement: Informed consent for cases with approved IRB protocols was obtained from all subjects involved in those studies. In those cases, in accordance with the approved IRB protocols, oral or written informed consent was obtained from the participants. In the other cases, informed consent was not sought because they did not involve human subjects research.

Data Availability Statement: This study did not report data. 
Conflicts of Interest: The authors declare no conflict of interest.

\section{References}

1. United Nations. Open Working Group on Sustainable Development Goals. 2015. Available online: https://sustainabledevelopment. un.org/owg.html (accessed on 14 July 2021).

2. Saner, R.; Yiu, L.; Nguyen, M. Monitoring the SDGs: Digital and Social Technologies to Ensure Citizen Participation, Inclusiveness and Transparency. Dev. Policy Rev. 2020, 38, 483-500. [CrossRef]

3. Von Schnurbein, G. (Ed.) Transitioning to Strong Partnerships for the Sustainable Development Goals; MDPI: Basel, Switzerland, 2020.

4. Barrantes Briceño, C.E.; Almada Santos, F.C. Knowledge Management, the Missing Piece in the 2030 Agenda and SDGs Puzzle. Int. J. Sustain. High. Educ. 2019, 20, 901-916. [CrossRef]

5. Klingenberg, B.; Rothberg, H.N. The Status quo of Knowledge Management and Sustainability Knowledge. Electron. J. Knowl. Manag. 2020, 18, 136-148. [CrossRef]

6. Abma, T.A.; Cook, T.; Rämgård, M.; Kleba, E.; Harris, J.; Wallerstein, N. Social Impact of Participatory Health Research: Collaborative Non-linear Processes of Knowledge Mobilization. Educ. Action Res. 2017, 25, 489-505. [CrossRef]

7. Anderson, C.; McLachlan, S. Transformative Research as Knowledge Mobilization: Transmedia, Bridges and Layers. Action Res. 2016, 14, 295-317. [CrossRef]

8. Bennet, A.; Bennet, B.; Fafard, K.; Fonda, M.; Lamond, T.; Messer, L.; Vaugeois, N. Knowledge Mobilization in the Social Sciences and Humanities: Moving from Research to Action, 2nd ed.; MQI Press/SSHRC of Canada: Marlinton, WV, USA, 2013.

9. Phipps, D.; Cummins, J.; Pepler, D.J.; Craig, W.; Cardinal, S. The Co-produced Pathway to Impact Describes Knowledge Mobilization Processes. J. Community Engagem. Scholarsh. 2016, 9, 31-40.

10. Kindon, S.; Pain, R.; Kesby, M. Participatory Action Research: Origins, Approaches and Methods; Routledge: New York, NY, USA, 2007.

11. McIntyre, A. Participatory Action Research; Sage: Thousand Oaks, CA, USA, 2008.

12. Grilli, N.D.M.; Andrade, M.M.D.; Xavier, L.Y.; Santos, C.R.; Stori, F.T.; Carrilho, C.D.; Otavio Nunes, F.; Peres, C.M.; Vivacqua, M.; Serafini, T.Z.; et al. Step by Step: A Participatory Action-research Framework to Improve Social Participation in Coastal Systems. Ambiente Soc. 2021, 24, 1-22. [CrossRef]

13. Keahey, J. Sustainable Development and Participatory Action Research: A Systematic Review. Syst. Pr. Action Res. 2021, 34, 291-306. [CrossRef]

14. Méndez, V.E.; Caswell, M.; Gliessman, S.R.; Cohen, R. Integrating Agroecology and Participatory Action Research (PAR): Lessons from Central America. Sustainability 2017, 9, 705. [CrossRef]

15. Wedemeyer-Strombel, K.R.; Peterson, M.; Sanchez, R.N.; Chavarría, S.; Valle, M.; Altamirano, E.; Gadea, V.; Sowards, S.K.; Tweedie, C.E.; Liles, M.J. Engaging Fishers' Ecological Knowledge for Endangered Species Conservation: Four Advantages to Emphasizing Voice in Participatory Action Research. Front. Commun. 2019, 4, 30. [CrossRef]

16. Bettencourt, G.M. Embracing problems, processes, and contact zones: Using youth participatory action research to challenge adultism. Action Res. 2020, 18, 153-170. [CrossRef]

17. Bleijenbergh, I. Transformational change towards gender equality: An autobiographical reflection on resistance during participatory action research. Organization 2017, 25, 131-138. [CrossRef] [PubMed]

18. Weber-Pillwax, C. When Research Becomes a Revolution: Participatory Action Research with Indigenous Peoples. In Education, Participatory Action Research, and Social Change; Kapoor, D., Jordan, S., Eds.; Palgrave Macmillan: New York, NY, USA, 2009; pp. $45-58$.

19. Perz, S.G. Crossing Boundaries for Collaboration: Conservation and Development Projects in the Amazon; Lexington Books: Lanham, MD, USA, 2016.

20. Fitzgerald, T. Powerful Voices and Powerful Stories: Reflections on the Challenges and Dynamics of Intercultural Research. J. Intercult. Stud. 2004, 25, 233-245. [CrossRef]

21. Kreps, G.L.; Maibach, E. Transdisciplinary Science: The Nexus Between Communication and Public Health. J. Commun. 2008, 58, 732-748. [CrossRef]

22. Steger, C.; Klein, J.A.; Reid, R.S.; Lavorel, S.; Tucker, C.; Hopping, K.A.; Marchant, R.; Teel, T.; Cuni-Sanchez, A.; Dorji, T.; et al. Science with society: Evidence-based guidance for best practices in environmental transdisciplinary work. Glob. Environ. Chang. 2021, 68, 102240. [CrossRef]

23. Williams, J.; Fam, D.; Mellick Lopes, A. Creating Knowledge: Visual Communication Design Research in Transdisciplinary Projects. In Transdisciplinary Research and Practice for Sustainability Outcomes; Fam, D., Palmer, J., Reidy, D., Mitchell, C., Eds.; Routledge: New York, NY, USA, 2017; pp. 155-171.

24. Inglis, J.T. (Ed.) Traditional Ecological Knowledge: Concepts and Cases; International Program on TEK/IDRC: Ottawa, ON, Canada, 1993.

25. Reyes-García, V. The Values of Traditional Ecological Knowledge. In Handbook of Ecological Economics; Martínez-Alier, J., Muradian, J., Eds.; Edward Elgar: Northampton, MA, USA, 2015; pp. 283-306.

26. Pierotti, R.; Wildcat, D. Traditional Ecological Knowledge: The Third Alternative (Commentary). Ecol. Appl. 2000, 10, 1333-1340. [CrossRef]

27. Gómez-Baggethun, E.; Reyes-Garcia, V. Reinterpreting Change in Traditional Ecological Knowledge. Hum. Ecol. 2013, 41, 643-647. [CrossRef] 
28. Gómez-Baggethun, E.; Corbera, E.; Reyes-García, V. Traditional Ecological Knowledge and Global Environmental Change: Research findings and policy implications. Ecol. Soc. 2013, 18, 72. [CrossRef]

29. Whyte, K.P. On the role of traditional ecological knowledge as a collaborative concept: A philosophical study. Ecol. Process. 2013, 2, 7. [CrossRef]

30. Caxaj, C.S. Indigenous Storytelling and Participatory Action Research: Allies Toward Decolonization? Reflections From the Peoples' International Health Tribunal. Glob. Qual. Nurs. Res. 2015, 1, 1-12. [CrossRef]

31. Hall, B.L.; Tandon, R. Decolonization of knowledge, epistemicide, participatory research and higher education. Res. All 2017, 1, 6-19. [CrossRef]

32. Jimmy, R.; Allen, W.; Anderson, V. Kindred Practice: Experiences of a Research Group Working Towards Decolonization and Indigenization in the Everyday. Educ. Matters 2015, 3, 1-13.

33. Ritenburg, H.; Young Leon, A.E.; Linds, W.; Nadeau, D.M.; Goulet, L.M.; Kovatch, M.; Marshall, M. Embodying Decolonization Methodologies and Indigenization. AlterNative Int. J. Indig. Peoples 2014, 10, 67-80. [CrossRef]

34. Arocena, R.; Sutz, J. Science, Technology and Innovation for What? Exploring the Democratization of Knowledge as an Answer. In Research Handbook on Innovation Governance for Emerging Economies: Toward Better Models; Kuhlmann, S., Ordoñez-Matamoros, G., Eds.; Edward Elgar: Northampton, MA, USA, 2017; pp. 377-404.

35. Holbrook, J.B. Open Science, Open Access, and the Democratization of Knowledge. Issues Sci. Technol. 2009, 35, $26-28$.

36. Batallan, G.; Dente, L.; Ritta, L. Anthropology, participation, and the democratization of knowledge: Participatory research using video with youth living in extreme poverty. Int. J. Qual. Stud. Educ. 2017, 30, 464-473. [CrossRef]

37. Kapoor, D. Research as knowledge democratization, mobilization and social action: Pushing back on casteism in contexts of caste humiliation and social reproduction in schools in India. Educ. Action Res. 2018, 27, 57-74. [CrossRef]

38. Contandriopoulos, D.; Lemire, M.; Denis, J.-L.; Tremblay, E. Knowledge Exchange Processes in Organizations and Policy Arenas: A Narrative Systematic Review of the Literature. Milbank Q. 2010, 88, 444-483. [CrossRef]

39. Mitton, C.; Adair, C.E.; Mckenzie, E.; Patten, S.; Perry, B.W. Knowledge Transfer and Exchange: Review and Synthesis of the Literature. Milbank Q. 2007, 85, 729-768. [CrossRef]

40. Fazey, I.; Evely, A.C.; Reed, M.S.; Stringer, L.C.; Kruijsen, J.; White, P.C.; Newsham, A.; Jin, L.; Cortazzi, M.; Phillipson, J.; et al. Knowledge exchange: A review and research agenda for environmental management. Environ. Conserv. 2013, 40, 19-36. [CrossRef]

41. Phillipson, J.; Lowe, P.; Proctor, A.; Ruto, E. Stakeholder engagement and knowledge exchange in environmental research. J. Environ. Manag. 2012, 95, 56-65. [CrossRef]

42. Duchelle, A.E.; Biedenweg, K.; Lucas, C.; Virapongse, A.; Radachowsky, J.; Wojcik, D.J.; Londres, M.; Bartels, W.-L.; Alvira, D.; Kainer, K.A. Graduate Students and Knowledge Exchange with Local Stakeholders: Possibilities and Preparation. Biotropica 2009, 41, 578-585. [CrossRef]

43. Mendoza, E.R.; Perz, S.G.; da Silva, S.S.; Brown, I.F.; Pinheiro, P.S. Revisiting the knowledge exchange train: Scaling up dialogue and partnering for participatory regional planning. J. Environ. Plan. Manag. 2014, 57, 384-402. [CrossRef]

44. Ellwood, E.; Crimmins, S.; Miller-Rushing, A. The Role of Citizen Science in Biological Conservation. Biol. Conserv. 2017, 208, 1-188. [CrossRef]

45. Fischhoff, B. The Sciences of Science Communication. In Proceedings of the National Academy of Sciences, Washington, DC, USA, 21-22 May 2012; Volume 110, pp. 14033-14039.

46. Kobori, H.; Dickinson, J.L.; Washitani, I.; Sakurai, R.; Amayo, T.; Komatsu, N.; Kitamura, W.; Takagawa, S.; Koyama, K.; Ogawara, T.; et al. Citizen Science: A New Approach to Advance Ecology, Education, and Conservation. Ecol. Res. 2016, $31,1-19$. [CrossRef]

47. Conrad, C.C.; Hilchey, K.G. A review of citizen science and community-based environmental monitoring: Issues and opportunities. Environ. Monit. Assess. 2011, 176, 273-291. [CrossRef] [PubMed]

48. Goldsmith, F.B. (Ed.) Monitoring for Conservation and Ecology; Springer: New York, NY, USA, 2012.

49. Wenger-Trayner, E.; Fenton-O'Creevy, M.P.; Hutchinson, S.; Kubiak, C.; Wenger-Trayner, B. Learning in Landscapes of Practice: Boundaries, Identity, and Knowledgeability in Practice-based Learning; Routledge: New York, NY, USA, 2015.

50. Nel, J.L.; Roux, D.; Driver, A.; Hill, L.; Maherry, A.C.; Snaddon, K.; Petersen, C.R.; Smith-Adao, L.B.; van Deventer, H.; Reyers, B. Knowledge co-production and boundary work to promote implementation of conservation plans. Conserv. Biol. 2016, 30, 176-188. [CrossRef] [PubMed]

51. Norstrom, A.V.; Cvitanovic, C.; Österblom., H. Principles for Knowledge Co-production in Sustainability Research. Nat. Sustain. 2020, 3, 182-190. [CrossRef]

52. Schönenberg, R.; Boy, J.; Hartberger, K.; Schumann, C.; Guggenberger, G.; Siebold, M.; Lakes, T.; Lamparter, G.; Schindewolf, M.; Schaldach, R.; et al. Experiences of inter- and transdisciplinary research-A trajectory of knowledge integration within a large research consortium. Erdkunde 2017, 71, 177-193. [CrossRef]

53. Van der Hel, S. New Science for Global Sustainability? The Institutionalisation of Knowledge Co-production in Future Earth. Environ. Sci. Policy 2016, 61, 165-175. [CrossRef]

54. Burns, J.C.; Cooke, D.Y.; Schweidler, C. A Short Guide to Community Based Participatory Action Research. Los Angeles: Healthy City/Advancement Project. 2011. Available online: https://www.labor.ucla.edu/wp-content/uploads/2015/03/A-Short-Guide-toCommunity-Based-Participatory-Action-Research.pdf (accessed on 17 July 2021). 
55. Ehde, D.M.; Wegener, S.T.; Williams, R.M.; Ephraim, P.L.; Stevenson, J.E.; Isenberg, P.J.; MacKenzie, E.J. Developing, Testing, and Sustaining Rehabilitation Interventions via Participatory Action Research. Arch. Phys. Med. Rehabil. 2013, 94 (Suppl. 1), S30-S42. [CrossRef]

56. Janssen, J.; Hale, L.; Mirfin-Veitch, B.; Harland, T. Building the Research Capacity of Clinical Physical Therapists Using a Participatory Action Research Approach. Phys. Ther. 2013, 93, 923-934. [CrossRef]

57. Jensen, C.; Kotaish, M.; Chopra, A.; Jacob, K.A.; Widekar, T.I.; Alam, R. Piloting a Methodology for Sustainability Education: Project Examples and Exploratory Action Research Highlights. Emerg. Sci. J. 2019, 3, 312-326. [CrossRef]

58. Macfarlane, A.; O’Donnell, C.; Mair, F.; De Brún, M.O.; De Brún, T.; Spiegel, W.; Muijsenbergh, M.V.D.; Van Weel-Baumgarten, E.; Lionis, C.; Burns, N.; et al. REsearch into implementation STrategies to support patients of different ORigins and language background in a variety of European primary care settings (RESTORE): Study protocol. Implement. Sci. 2012, 7, 111. [CrossRef]

59. Stringer, E. Action Research in Education; Pearson: Upper Saddle River, NJ, USA, 2008.

60. Fine, E.; Torre, M.E. Critical Participatory Action Research: A Feminist Project for Validity and Solidarity. Psychol. Women Q. 2019, 43, 433-444. [CrossRef]

61. Houh, E.M.S.; Kalsem, K. Theorizing Legal Participatory Action Research: Critical Race/Feminism and Participatory Action Research. Qual. Inq. 2015, 21, 262-276. [CrossRef]

62. Glassman, M.; Erdem, G. Participatory Action Research and Its Meanings: Vivencia, Praxis, Conscientization. Adult Educ. Q. 2014, 64, 206-221. [CrossRef]

63. Davidson, E.A.; De Araújo, A.C.; Artaxo, P.; Balch, J.K.; Brown, I.F.; Bustamante, M.M.; Coe, M.T.; DeFries, R.S.; Keller, M.; Longo, M.; et al. The Amazon basin in transition. Nature 2012, 481, 321-328. [CrossRef]

64. Nagy, L.; Forsberg, B.; Artaxo, P. (Eds.) Interactions between Biosphere, Atmosphere and Human Land Use in the Amazon Basin; Springer: Berlin, Germany, 2016.

65. Fisher, J.; Stutzman, H.; Vedoveto, M.; Delgado, D.; Rivero, R.; Quertehuari Dariquebe, W.; Seclén Contreras, L.; Souto, T.; Harden, A.; Rhee, S. Collaborative Governance and Conflict Management: Lessons Learned and Good Practices from a Case Study in the Amazon Basin. Soc. Nat. Resour. 2020, 33, 538-553. [CrossRef]

66. Sobreiro, T. Urban-Rural Livelihoods, Fishing Conflicts and Indigenous Movements in the Middle Rio Negro Region of the Brazilian Amazon. Bull. Lat. Am. Res. 2015, 34, 53-69. [CrossRef]

67. Vasquez, P.I. Oil Sparks in the Amazon: Local Conflicts, Indigenous Populations, and Natural Resources; Georgia University Press: Athens, Greece, 2014.

68. Correa, J.; Van Der Hoff, R.; Rajão, R. Amazon Fund 10 Years Later: Lessons from the World's Largest REDD+ Program. Forests 2019, 10, 272. [CrossRef]

69. Kauano, E.E.; Silva, J.M.C.; Filho, J.A.F.D.; Michalski, F. Do protected areas hamper economic development of the Amazon region? An analysis of the relationship between protected areas and the economic growth of Brazilian Amazon municipalities. Land Use Policy 2020, 92, 104473. [CrossRef]

70. Nepstad, D.; Soares-Filho, B.S.; Merry, F.; Lima, A.; Moutinho, P.; Carter, J.; Bowman, M.; Cattaneo, A.; Rodrigues, H.; Schwartzman, S.; et al. The End of Deforestation in the Brazilian Amazon. Science 2009, 326, 1350-1351. [CrossRef]

71. Athayde, S.; Silva-Lugo, S.; Schmink, M.; Kaiabi, A.; Heckenberger, M. Reconnecting Art and Science for Sustainability: Learning from Indigenous Knowledge through Participatory Action-Research in the Amazon. Ecol. Soc. 2017, 22, 36. [CrossRef]

72. Moreira, P.F.; Gamu, J.K.; Inoue, C.Y.A.; Athayde, S.; Seixas, S.R.D.C.; Viola, E. South-South Transnational Advocacy: Mobilizing Against Brazilian Dams in the Peruvian Amazon. Glob. Environ. Politics 2019, 19,77-98. [CrossRef]

73. Ungar, P.; Strand, R. Inclusive Protected Area Management in the Amazon: The Importance of Social Networks over Ecological Knowledge. Sustainability 2012, 4, 3260-3278. [CrossRef]

74. Castellanet, C.; Jordan, C.F. Participatory Action Research in Natural Resource Management: A Critique of the Method Based on Five Years Research in the Transamazonica Region of Brazil; Routledge: New York, NY, USA, 2004.

75. Shanley, P. Science for the Poor: How One Woman Challenged Researchers, Ranchers and Loggers in Amazonia. Ecol. Soc. 2006, 11, 28. [CrossRef]

76. Adger, W.N.; Barnett, J.; Brown, K.; Marshall, N.; O’Brien, K. Cultural dimensions of climate change impacts and adaptation. Nat. Clim. Chang. 2012, 3, 112-117. [CrossRef]

77. Crate, S.A.; Nuttall, M. Anthropology and Climate Change: From Encounters to Actions; Routledge: New York, NY, USA, 2016.

78. Orlove, B. The Past, the Present and Some Possible Futures of Adaptation. In Adaptation Now. Adapting to Climate Change: Thresholds, Values, Governance; Adger, W.N., Lorenzoni, I., O’Brien, K.L., Eds.; Cambridge University Press: Cambridge, UK, 2009.

79. Ford, J.D.; King, N.; Galappaththi, E.K.; Pearce, T.; McDowell, G.; Harper, S.L. The Resilience of Indigenous Peoples to Environmental Change. One Earth 2020, 2, 532-543. [CrossRef]

80. Rosero, M.C. The Important Things for Us: Resilience and Relationality in Colombian Ethnic Group Contexts during Times of Crisis. Ph.D. Thesis, University of Florida, Gainesville, FL, USA, 2019.

81. Adger, W.N.; Brown, K.; Waters, L. Resilience. In The Oxford Handbook of Climate Change and Society; Dryzek, J., Norgaard, R., Schlosberg, D., Eds.; Oxford University Press: New York, NY, USA, 2011.

82. Galarza-Villamar, J.A.; Leeuwis, C.; Pila-Quinga, G.M.; Cecchi, F.; Párraga-Lema, C.M. Local understanding of disaster risk and livelihood resilience: The case of rice smallholders and floods in Ecuador. Int. J. Disaster Risk Reduct. 2018, 31, 1107-1120. [CrossRef] 
83. Escobar, A. Designs for the Pluriverse: Radical Interdependence, Autonomy, and the Making of Worlds; Duke University Press: Durham, NC, USA, 2018.

84. Blaser, M. Ontological Conflicts and the Stories of Peoples in Spite of Europe: Toward a Conversation on Political Ontology. Curr. Anthropol. 2013, 54, 547-568. [CrossRef]

85. De La Cadena, M.; Risør, H.; Feldman, J. Aperturas Onto-epistémicas: Conversaciones con Marisol de la Cadena. Antípoda Rev. Antropol. Y Arqueol. 2018, 32, 159-177. [CrossRef]

86. SERNAP. Evaluación Ambiental Estratégica del TIPNIS-EAE; Servicio Nacional de Areas Protegidas SERNAP/RUMBOL srl: La Paz, Bolivia, 2011.

87. Baudoin Farah, C.A. "Volver a Habler con la Gente del Agua": Meanders of Indigenous Autonomy in the Isiboro Sécure Indigenous Territory and National Park (TIPNIS), Bolivia. Ph.D. Thesis, University of Florida, Gainesville, FL, USA, 2019.

88. Paz, S. Dos Actores, Dos Modos de Vida y un Sector Social en Ascenso: Los Colonizadores. 2012. Available online: https:/ / cedib.org/post_type_titulares/el-tipnis-en-el-centro-del-interes-global-bolpress-4-9-2012 (accessed on 22 December 2021).

89. Doria, C.R.C.; Dutka-Gianelli, J.; de Sousa, S.T.B.; Chu, J.; Garlock, T.M. Understanding Impacts of Dams on Small-scale Fisheries of the Madeira River through the Lens of the Fisheries Performance Indicators. Mar. Policy 2021, 125, 104261. [CrossRef]

90. Santos, R.E.; Pinto-Coelho, R.M.; Fonseca, R.; Simões, N.R.; Zanchi, F.B. The decline of fisheries on the Madeira River, Brazil: The high cost of the hydroelectric dams in the Amazon Basin. Fish. Manag. Ecol. 2018, 25, 380-391. [CrossRef]

91. Allegretti, M.H. Extractive Reserves: An Alternative for Reconciling Development and Environmental Conservation in Amazonia. In Alternatives to Deforestation: Steps Towards Sustainable Use of the Amazon Rain Forest; Anderson, A.B., Ed.; Columbia University Press: New York, NY, USA, 1990.

92. Maciel, R.C.G.; Cavalcanti, F.C.D.S.; de Souza, E.F.; de Oliveira, O.F.; Filho, P.G.C. The "Chico Mendes" extractive reserve and land governance in the Amazon: Some lessons from the two last decades. J. Environ. Manag. 2018, 223, 403-408. [CrossRef]

93. Maciel, R.C.G.; Filho, P.G.C.; Souza, E.F. Distribuição de Renda e Pobreza na Floresta Amazônica: Um Estudo a partir da Reserva Extrativista (RESEX) Chico Mendes. Rev. De Estud. Sociais 2014, 16, 136-153. [CrossRef]

94. Dougill, A.J.; Stringer, L.; Leventon, J.; Riddell, M.; Rueff, H.; Spracklen, D.V.; Butt, E. Lessons from community-based payment for ecosystem service schemes: From forests to rangelands. Philos. Trans. R. Soc. B Biol. Sci. 2012, 367, 3178-3190. [CrossRef]

95. Skutch, M. (Ed.) Community Forest Monitoring for the Carbon Market: Opportunities under REDD; Earthscan: London, UK, 2011.

96. Pause, M.; Schweitzer, C.; Rosenthal, M.; Keuck, V.; Bumberger, J.; Dietrich, P.; Heurich, M.; Jung, A.; Lausch, A. In Situ/Remote Sensing Integration to Assess Forest Health-A Review. Remote Sens. 2016, 8, 471-482. [CrossRef]

97. Ribeiro, S.C.; Selaya, N.G.; Perz, S.G.; Brown, F.; Schmidt, F.A.; Silva, R.C.; Lima, F. Aligning conservation and development goals with rural community priorities: Capacity building for forest health monitoring in an extractive reserve in Brazil. Ecol. Soc. 2020, 25, 5. [CrossRef]

98. Lausch, A.; Erasmi, S.; King, D.J.; Magdon, P.; Heurich, M. Understanding Forest Health with Remote Sensing -Part I-A Review of Spectral Traits, Processes and Remote-Sensing Characteristics. Remote. Sens. 2016, 8, 1029. [CrossRef]

99. E Trumbore, S.; Brando, P.M.; Hartmann, H. Forest health and global change. Science 2015, 349, 814-818. [CrossRef] [PubMed]

100. Marques, E.L.; Ribeiro, S.C.; Lima, F.R.; Schmidt, F.A.; Silva, R.C.; Brown, I.F.; Selaya, N.G.; Perz, S.G. Livro de Dinâmicas: Projeto Saúde das Florestas; Associação SOS Amazônia: Rio Branco, Brazil, 2018.

101. Rioja Ballivián, G. Floods in the Amazon Basin and the Talking Object: Emerging Perspectives for the Social Assessment of Disasters. 2021. Available online: https:/ / www.researchgate.net/publication/349502539 (accessed on 5 August 2021).

102. Fuentes, H. Medias Trinacionales en Gestion de Riesgos de Inundaciones y su Aportación a las Innovaciones Tecnologicas y de Comunicación en la Cuenca Trinacional del Alto Acre. 2017. Available online: http://observatoriogeograficoamericalatina.org mx/egal16/Teoriaymetodo/Investigacion/17.pdf (accessed on 5 August 2021).

103. Perales Yabar, L.M. Articulando el Desarrollo en Zona de Frontera: Caso Tahuamanu: MAP-Madre de Dios, Peru-Acre, Brasil -Pando, Bolivia. 2019. Available online: http://www.descentralizacion.gob.pe/wp-content/uploads/2019/07/Tahuamanu.pdf (accessed on 17 July 2021).

104. Brown, F.; Perales Yabar, L.M.; Rioja Ballivián, G.; Pereira Santos, G.L. Colaboração para Enfrentar os Riscos Crescentes de Desastres na Região MAP (Madre de Dios/Peru-Acre/Brasil-Pando/Bolívia). MAPiense 2019, 3, 54-58. Available online: https://www.herencia.org.bo/webdocs/publicaciones/Mapiense-3.pdf (accessed on 5 August 2021).

105. Rioja Ballivián, G.; de Oliveira, I. Inundación de 2015: Vulnerabilidad de los Asentamientos de la Cuenca Alta Trinacional del Río Acre. 2020. Available online: https://www.researchgate.net/publication/339747398 (accessed on 5 August 2021 ).

106. Rioja Ballivián, G. El Ancho Camino a una Tormenta Perfecta. 2021. Available online: https://www.researchgate.net/publication/ 349044354 (accessed on 5 August 2021).

107. Souza da Silva, S.; Soares de Oliveira, I.; Oighenstein Anderson, L.; Fearnside, P.M.; Flores de Melo, A.W.; Gomes da Costa, J.; Negreiros de Almeidam, M.R.; Brown, I.F. Incêndios Florestais e Queimadas na Amazônia Sul Ocidental. MAPiense 2019, 3, 27-36. Available online: https://www.researchgate.net/publication/353907471_Incendios_florestais_e_queimadas_na_Amazonia_Sul_ Ocidental (accessed on 5 August 2021).

108. Mendoza, E.; Perz, S.; Aguilar, C.; Alarcón, G.; Brown, F.; Carballo, J.; Chavez, A.; Chavez, J.; Cullman, G.; de los Rios, M.; et al. The Knowledge Exchange Train: A Model for Capacity Building for Participatory Governance. Dev. Pract. 2007, 17, 791-799. [CrossRef] 
109. Margalida, A.; Donázar, J.A. Fake News and Vultures. Nat. Sustain. 2020, 3, 492-493. [CrossRef]

110. Nichols, T. The Death of Expertise: The Campaign against Established Knowledge and Why It Matters; Oxford University Press: Oxford, UK, 2017. 